\title{
Anthropogenic and climatic impacts on a coastal environment in the Baltic Sea over the last 1000 years
}

\section{Ning, Wenxin}

2018-03

Ning , W , Nielsen , A B , Norbäck Ivarsson , L , Jilbert , T S , Åkesson , C , Slomp , C P , Andren , E , Broström , A \& Filipsson , H L 2018 , ' Anthropogenic and climatic impacts on a coastal environment in the Baltic Sea over the last 1000 years ' , Anthropocene , vol. 21, pp. 66-79 . https://doi.org/10.1016/j.ancene.2018.02.003

http://hdl.handle.net/10138/312113

https://doi.org/10.1016/j.ancene.2018.02.003

cc_by_nc_nd

acceptedVersion

Downloaded from Helda, University of Helsinki institutional repository.

This is an electronic reprint of the original article.

This reprint may differ from the original in pagination and typographic detail.

Please cite the original version. 


\section{Accepted Manuscript}

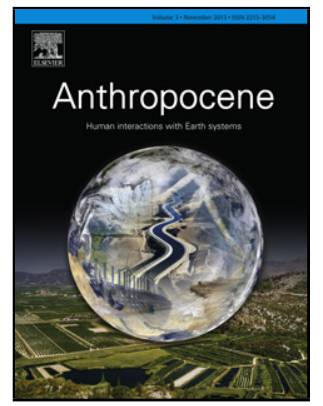

Title: Anthropogenic and climatic impacts on a coastal environment in the Baltic Sea over the last 1000 years

Authors: W. Ning, A.B. Nielsen, L. Norbäck Ivarsson, T.

Jilbert, C.M. Åkesson, C.P. Slomp, E. Andrén, A. Broström, H.L. Filipsson

PII: S2213-3054(16)30129-1

DOI: https://doi.org/10.1016/j.ancene.2018.02.003

Reference: ANCENE 165

To appear in:

Received date: 6-12-2016

Revised date: $\quad$ 13-2-2018

Accepted date: $\quad$ 16-2-2018

Please cite this article as: Ning, W., Nielsen, A.B., Ivarsson, L.Norbäck, Jilbert, T., Åkesson, C.M., Slomp, C.P., Andrén, E., Broström, A., Filipsson, H.L., Anthropogenic and climatic impacts on a coastal environment in the Baltic Sea over the last 1000 years.Anthropocene https://doi.org/10.1016/j.ancene.2018.02.003

This is a PDF file of an unedited manuscript that has been accepted for publication. As a service to our customers we are providing this early version of the manuscript. The manuscript will undergo copyediting, typesetting, and review of the resulting proof before it is published in its final form. Please note that during the production process errors may be discovered which could affect the content, and all legal disclaimers that apply to the journal pertain. 


\section{Anthropogenic and climatic impacts on a coastal environment in the Baltic Sea over the last 1000 years}

W. Ning ${ }^{\mathrm{a}}$, A. B. Nielsen ${ }^{\mathrm{a}, \mathrm{b}}$, L. Norbäck Ivarsson ${ }^{\mathrm{c}}$, T. Jilbert ${ }^{\mathrm{d}, \mathrm{e}}$, C. M. Åkesson ${ }^{\mathrm{a}, \mathrm{f}}$, C.P. Slomp ${ }^{\mathrm{d}}$, E. Andrén ${ }^{c}$, A. Broström ${ }^{\mathrm{g}}$ and H.L. Filipsson ${ }^{\mathrm{a}^{*}}$

${ }^{\text {a }}$ Department of Geology, Lund University, Sölvegatan 12, 22362 Lund, Sweden

${ }^{\mathrm{b}}$ Department of Physical Geography and Ecosystems Science, Lund University, Sölvegatan 12, 22362 Lund, Sweden

${ }^{\mathrm{c}}$ School of Natural Sciences, Technology and Environmental Studies, Södertörn University, Alfred Nobels allé 7, 14189 Huddinge, Sweden

${ }^{\mathrm{d}}$ Department of Earth Sciences, Faculty of Geosciences, Utrecht University, P.O. Box 80.021, 3508 TA Utrecht, Netherlands

${ }^{\text {e }}$ Department of Environmental Sciences, P.O. Box 65, 00014 University of Helsinki, Helsinki, Finland

${ }^{\mathrm{f}}$ Department of Biological Science, Florida Institute of Technology, 150 W. University Blvd., Melbourne, FL 32901, USA

g The Archaeologists, Swedish National Historical Museums, Odlarevägen 5, 22660 Lund, Sweden

*Corresponding author: Helena L. Filipsson（helena.filipsson@geol.lu.se） 
Abstract

Coastal environments have experienced large ecological changes as a result of human activities over the last 100-200 years. To understand the severity and potential consequences of such changes, paleoenvironmental records provide important contextual information. The Baltic Sea coastal zone is naturally a vulnerable system and subject to significant human-induced impacts. To put the recent environmental degradation in the Baltic coastal zone into a long-term perspective, and to assess the natural and anthropogenic drivers of environmental change, we present sedimentary records covering the last 1000 years obtained from a coastal inlet (Gåsfjärden) and a nearby lake (Lake Storsjön) in Sweden. We investigate the links between a pollen-based land cover reconstruction from Lake Storsjön and paleoenvironmental variables from Gåsfjärden itself, including diatom assemblages, organic carbon $(\mathrm{C})$ and nitrogen $(\mathrm{N})$ contents, stable $\mathrm{C}$ and $\mathrm{N}$ isotopic ratios, and biogenic silica contents. The Lake Storsjön record shows that regional land use was characterized by small-scale agricultural activity between 900 and $1400 \mathrm{CE}$, which slightly intensified between 1400 and $1800 \mathrm{CE}$. Substantial expansion of cropland was observed between 1800 and $1950 \mathrm{CE}$, before afforestation between 1950 and $2010 \mathrm{CE}$. From the Gåsfjärden record, prior to $1800 \mathrm{CE}$, relatively minor changes in the diatom and geochemical proxies were found. The onset of cultural eutrophication in Gåsfjärden can be traced to the 1800 s and intensified land use is identified as the main driver. Anthropogenic activities in the 20th century have caused unprecedented ecosystem changes in the coastal inlet, as reflected in the diatom composition and geochemical proxies.

Key words: land use, eutrophication, mining, hypoxia, coastal area, Baltic Sea

\section{Introduction}

Anthropogenic activities have globally caused substantial coastal ecosystem changes over the last 100-200 years (e.g. Rabalais et al. 2010; Conley et al. 2011; Zonneveld et al. 2012; Yasuhara et al. 2012). The increased anthropogenic pressures, including warming, eutrophication, deoxygenation, and pollution by heavy metals and organic toxicants, have created a need to both understand the severity and potential outcomes of such changes as well as to support evidence-based environmental management strategies. To distinguish particular human activities amongst the multiple drivers of ecosystem change we need to, however, consider longer time scales than those available from observational ecological - and instrumental records. This can be achieved by combining paleoenvironmental records of changes in land use, climate, and the environment in the coastal zone. 
In the Baltic Sea region, the use of artificial fertilizers increased substantially after the 1950s and eutrophication became widespread (Elmgren 2001; HELCOM 2009; Gustafsson et al. 2012). An assessment of the eutrophication status for 189 areas in the Baltic Sea indicates that the majority of the coastal and open waters are affected by eutrophication (Andersen et al. 2011). Enhanced primary production and subsequent decomposition of organic matter in the poorly ventilated bottom water have caused a significant expansion of hypoxia $\left(\mathrm{O}_{2}<2 \mathrm{mg} \mathrm{L}^{-1}\right)$ in the deep basins (Carstensen et al. 2014). Cyanobacteria blooms occur frequently due to the large nutrient pool in the water column, in combination with a decline of phosphorus retention by the sediment under hypoxic conditions (Vahtera et al. 2007; Conley et al. 2009). Furthermore, water transparency, in particular during the spring season, has decreased over the past decades as eutrophication intensified (Fleming-Lehtinen and Laamanen 2012). While reductions in nitrogen and phosphorus loads since the 1980s are leading to an improvement of water quality in many regions (Andersen et al. 2015), eutrophication-related problems are expected to persist over the coming decades. This is due to the long residence time of nutrients in the Baltic Sea (Gustafsson et al. 2012) and other legacy effects such as the increased oxygen demand of organic-rich sediments (e.g. Reed et al. 2011).

The Baltic Sea coastal zone contains over $20 \%$ of all known hypoxic sites worldwide and although the present areal distribution of oxygen deficiency is known, insights into the long-term trends on a millennial scale are lacking (Conley et al. 2011). In the Baltic Sea coastal areas, enhanced primary production (Savage et al. 2010), increased bottom water oxygen depletion (Conley et al. 2011), and altered diatom composition (Andrén 1999; Tuovinen et al. 2010) have occurred during the last 100 years. However, human activities, including deforestation and agriculture, potentially began to impact coastal ecosystems much earlier (Åkesson et al. 2015). Agriculture was first established in the region around 4000 years before the Common Era (BCE), in the early Neolithic (Lagerås, 1996). A welldocumented expansion of agricultural open land in southern Sweden occurred during the Late Bronze Age (1100-500 BCE), at the expense of former forest and woodland areas (Pedersen and Widgren 2011). At 1000-800 BCE, agriculture transformed into more efficient farming with the application of iron tools, where cleared, permanent, and manured fields resulted in more intense forest clearance, which had consequences for the degradation of soils through leaching and erosion (Welinder 2011). In the early centuries of the Common Era (CE), a reorganization of the agrarian society occurred and evidence of technological change is found in all aspects of farming, resulting in an expansion of grazing areas and an intensification of grain cultivation (Pedersen and Widgren 2011). A particularly important phase in the Swedish landscape development is the Early Medieval period, c. 1000-1300 CE. The sharp population increase around $1000 \mathrm{CE}$ can be ascribed to technological improvements in agriculture e.g. the wheeled plough (Emanuelsson 2009). Changes in social structure as well as settlement and cultivation arrangements were also characteristics of the Early Medieval period, where 
changes in land-ownership, settlement regulations, and the emergence of the open-field system were especially important (Myrdal 2011).

Our study region is located in the upland area of Småland, which has been a rather marginal area for agriculture (Lagerås, 2007), and may therefore have been more sensitive to variations in population pressure than more central agricultural areas in southern Sweden (Lagerås 2007; Nielsen and Odgaard 2010). Between 1350 and $1460 \mathrm{CE}$, Sweden was severely affected by the Black Death and a large number of farms were abandoned, especially small, remote farms which were overgrown by trees (Myrdal 2011). About $1550 \mathrm{CE}$, the Swedish population reached the same numbers as before the outbreak of plague but was now struck by a deterioration in climate towards cooler and probably also wetter conditions during the Little Ice Age (LIA; 1400-1850 CE). Despite the changing climate, the LIA population continued to increase and a new wave of land clearance took place, which continued into the 19th century (Myrdal 2011; Gadd 2011). During the last centuries, reforestation of grassland and in some cases also cropland has taken place in much of southern Sweden, and is seen in both local and regional pollen diagrams (e.g. Lagerås 1996; Åkesson et al. 2015) and on historical maps (e.g. Mazier et al. 2015). At present, the regional vegetation in our study area is dominated by managed coniferous woodland with smaller areas of cropland and grassland (Fig. 1).

Paleoenvironmental records may provide a longer temporal perspective and add further insight into the evolving human impact on aquatic systems (e.g. Battarbee et al. 2012). For example, historical hypoxia has been recorded during three time periods in the open Baltic Sea; about 6000-2000 BCE, $50 \mathrm{BCE}-1150 \mathrm{CE}$, and from $1800 \mathrm{CE}$ until present (Zillén et al. 2008), with each period experiencing a different balance of natural and anthropogenic forcing. While the earliest hypoxic intervals during the Holocene Thermal Maximum (HTM) were strongly linked to climate- and isostasy-driven circulation changes (Zillén et al. 2008; Zillén and Conley 2010; Kabel et al. 2012; Ning et al. 2016a), hypoxia during the Medieval Climate Anomaly (MCA) has been suggested to be forced partly by land use change in the catchment (Zillén and Conley, 2010). Similarly, numerous paleolimnological studies indicate that changes in land use during past centuries resulted in early eutrophication of lake systems (e.g. Fritz 1989; Gaillard et al. 1991; Bradshaw et al. 2006). Paleoenvironmental reconstructions are an essential resource for assessing the balance between natural and human forcing, because multiple proxies can be assessed simultaneously. The last millennium contains two periods that are of specific interest when assessing the relative impacts of climate change and human impacts, especially land use change, on coastal environments. These periods are the Medieval Climate Anomaly (MCA; 900-1300 CE) and the Little Ice Age (LIA; 1400-1850 CE) (Seppä et al. 2009; Ljungqvist et al. 2012).

In this study, we reconstruct environmental changes in Gåsfjärden (Fig. 1), a coastal inlet in the western Baltic Proper, over the past 1000 years using various geochemical proxies and diatom stratigraphy. We then assess these paleoenvironmental proxies in the context of a regional land cover 
reconstruction based on the pollen record from nearby Lake Storsjön (Fig. 1), regional mining and industrial history drawn from historical sources, and known climatic variability associated with the MCA and LIA. This combined approach allows us to assess the relative importance of human activities and climate variability in determining environmental change in the coastal ecosystem of the Baltic Sea over the last millennium.

\section{Regional and historical setting}

Gåsfjärden is a fjord-like inlet on the east coast of Sweden, in the western part of the Baltic Proper (Fig. 1). The mean and maximum water depths are 10 and $51 \mathrm{~m}$, respectively. The inlet is today connected to the open sea through a narrow $(<500 \mathrm{~m})$ and shallow $(\mathrm{c} .7 \mathrm{~m})$ sill. There is an archipelago between the open Baltic Sea and the inlet (Fig. 1). The present land uplift in the area is about 1.5 $\mathrm{mm} /$ year (Rosentau et al. 2012) resulting in a slight shallowing of the inlet areas by about $1.5 \mathrm{~m}$ within the last millennium, the timeframe of this study (Ning et al. 2016b). From 1995 to 2012, hydrographic parameters were measured every second month, to a maximum water depth of $25 \mathrm{~m}$ at station SMHIV6-VMS by the Swedish Meteorological and Hydrological Institute (SMHI) (Fig. 1). During this time period (1995-2012), the surface water $(0-0.5 \mathrm{~m})$ temperature varied between $0-5^{\circ} \mathrm{C}$ in winter and $15-20^{\circ} \mathrm{C}$ in summer. A strong thermocline is present during the summer months. Surface water salinity (2-6) was relatively low during winter and spring, whereas bottom water (20-25 m) salinity (6-7) was stable. Average surface water concentrations of dissolved inorganic nitrogen (DIN), phosphate, and silicate in winter were 8.5, 0.5, and $66.5 \mu \mathrm{mol} \mathrm{L} \mathrm{L}^{-1}$, respectively. Relatively high chlorophyll a values $\left(3-10 \mu \mathrm{g} \mathrm{L}^{-1}\right)$ were recorded in April and October. Hypoxic bottom water typically occurs during August to October. Two rivers, Marströmmen and Botorpsströmmen (Fig. 1), drain into Gåsfjärden with an average total inflow of $\sim 10 \mathrm{~m}^{3} \mathrm{~s}^{-1}$ (SMHI 2003). Regional phytoplankton composition is dominated by diatoms and dinoflagellates during spring, and small flagellates and cyanobacteria during summer and autumn (Legrand et al. 2015).

Lake Storsjön has a surface area of $2.1 \mathrm{~km}^{2}$ and is located $90 \mathrm{~m}$ a.s.1., approximately $25 \mathrm{~km} \mathrm{NW}$ of Gåsfjärden (Fig. 1). The lake has a maximum water depth of $14 \mathrm{~m}$ (mean water depth $5 \mathrm{~m}$ ) and drains into the river system of Botorpsströmmen.

\section{FIG. 1}

Our study area is located on the southern rim of a $100,000 \mathrm{~km}^{2}$ ore-rich geological region of central Sweden (Stephens et al. 2009). Active mining from Solstad Gruva, a copper mine along the shore of Gåsfjärden, started in the 1630s and ended in 1920 (Hermansson 1966; Söderhielm and Sundblad 1996). It is possible that the copper mining started earlier, already by the end of the 15 th century, concurrently with the copper mine in the nearby Gladhammar (Hermansson 1966). There is evidence that older techniques, such as fire-setting, have been used at Solstad Gruva, suggesting early 
exploration (Hermansson 1966). In 1877, Solstad Gruva reached its deepest point of $356 \mathrm{~m}$. Another important industry near Gåsfjärden was the saw mill industry in the village of Blankaholm (Fig. 1), which started in 1886 and expanded greatly throughout the 1910-1920s (Fig. 1). With 150 employees it was the largest saw mill at that time in southern Sweden, but it ultimately closed down in 1979 . Today Blankaholm and the archipelago around Gåsfjärden is a popular area for tourism and sailing in the summer.

\section{Materials and methods}

In this study, sediment cores from both Gåsfjärden and Lake Storsjön were analyzed. Sediment cores from Gåsfjärden (57³4'21.3"N, 16³4'58.4"E) were collected using a combination of Piston and Gemini coring in August 2011 on the $R / V$ Ocean Surveyor (Fig. 1). The coring site has a water depth of $31 \mathrm{~m}$. Here, we focus on the Gåsfjärden sediments covering the last c. 1000 years, whereas the entire record is presented in Ning et al. (2016a). Measurements of organic carbon $\left(\mathrm{C}_{\text {org }}\right)$, nitrogen $\left(\mathrm{N}_{\text {tot }}\right)$, and biogenic silica (BSi) were based on the methods described by Verardo et al. (1990) and DeMaster (1981). The mass accumulation rate (MAR) of $\mathrm{C}_{\text {org }}$ and BSi were calculated using the sedimentation rate and the bulk density of the samples $\left(\rho_{\text {dry }}\right)$, e.g. $C_{\text {org }} \operatorname{MAR}=C_{\text {org }}(\%) \times$ sedimentation rate $\times \rho_{\text {dry }}$. For further details regarding these measurements, see Ning et al. (2016a). Additional analysis, including diatom analysis, $\mathrm{C}$ isotopes $\left(\delta^{13} \mathrm{C}\right)$, and $\mathrm{N}$ isotopes $\left(\delta^{15} \mathrm{~N}\right)$ are described below. In Lake Storsjön ( $\left.57^{\circ} 42^{\prime} \mathrm{N}, 16^{\circ} 14^{\prime} \mathrm{E}\right)$, a $4.5 \mathrm{~m}$ long sediment sequence capturing the Holocene was obtained in April, 2012 by combining sediment cores collected with a Russian corer and a HON-Kajak corer (Renberg 1991), at a water depth of $6.6 \mathrm{~m}$. Measurements of loss on ignition $\left(550^{\circ} \mathrm{C}\right)$ were used to correlate the overlapping lake cores and pollen analysis was carried out as described below. Here, we focus on the pollen-based reconstruction of regional land cover over the last 1000 years.

\subsection{Chronology of sediment records}

An age-depth model (Fig. 2AB) for the Lake Storsjön sediment sequence was established using the software CLAM (Blaauw 2010), based on four radiocarbon dates of terrestrial macrofossils, and ${ }^{210} \mathrm{~Pb}$ dating of the upper part of the sediment core, which were both measured at the Department of Geology, Lund University. The sediment ages for the upper $20 \mathrm{~cm}$ of the sediments were estimated based on the excess (unsupported) ${ }^{210} \mathrm{~Pb}$ activity, using the constant rate of supply method (CRS) (Appleby and Oldfield 1978) (Fig. 2B). For the chronology of the Gåsfjärden sediment sequence (Fig. 2C, 2D), five ${ }^{14} \mathrm{C}$ dating samples of terrestrial macrofossils together with ${ }^{210} \mathrm{~Pb}$ dating of the top sediments were used (Ning et al. 2016a).

\section{FIG. 2}

\subsection{Pollen analysis of Storsjön sediments}


Subsamples were prepared following the method of Berglund and Ralska-Jasiewiczowa (1986). The pollen keys of Faegri and Iversen (1989), Moore et al. (1991), and Beug (2004), together with the reference collection at the Department of Geology, Lund University were used to identify the pollen types. More than 1000 pollen grains were counted in each sample using a light microscope at $\mathrm{x} 400$ magnification. To estimate regional vegetation composition based on fossil pollen assemblages, the REVEALS model was applied (Sugita 2007), using a set of pollen productivity estimates (PPEs) from southern Scandinavia (Sugita et al. 1999; Broström et al. 2004; Nielsen 2004; Fredh et al. 2012). The analysis includes 23 predominately wind pollinated taxa for which PPEs are available. The taxa were grouped into five land cover types: 1) coniferous woodland, 2) deciduous woodland, 3) wetland, 4) grassland and 5) cropland, following Mazier et al. (2015). The diagram (Fig. 3) was divided into pollen assemblage zones (PAZ) based on a cluster analysis (CONISS) of the REVEALS reconstructed land cover percentages, and plotted using Tilia 1.7.16 (Grimm 1987). The land cover reconstruction using the REVEALS model represents the regional vegetation composition within a radius of approximately 50-100 km from Lake Storsjön (Hellman et al. 2008), and thus covers the catchment area for Gåsfjärden (Fig. 1).

\subsection{Diatom analysis of Gåsfjärden sediments}

Diatom samples were prepared according to the method described by Battarbee (1986) and mounted on permanent slides using Naphrax ${ }^{\mathrm{TM}}$. Diatoms were identified under an Olympus BX51 light microscope at x1000 magnification using oil immersion and Nomarski differential interference contrast. A minimum of 300 valves were counted at each level, excluding Chaetoceros spp. resting spores. The method for counting diatoms followed Schrader and Gersonde (1978). Floras used for diatom identification included Krammer and Lange-Bertalot (1986;1988;1991a;1991b), Snoeijs (1993), Snoeijs and Vilbaste (1994), Snoeijs and Potapova (1995), Snoeijs and Kasperovičienė (1996), Snoeijs and Balashova (1998), and Witkowski et al. (2000). The siliceous endoskeletons of the heterotrophic plankton Ebria tripartita were counted separately. Species including Epithemia sorex, E. adnata and E. turgida var. westermannii were merged and presented as Epithemia aggregate.

Statistical analyses of the diatom data were computed using the rioja and vegan packages in $\mathrm{R}$ x64 3.2.2 (Juggins 2014; Oksanen et al. 2015). Detrended Correspondence Analysis (DCA) and cluster analysis (CONISS) were performed, using taxa occurring with at least $2 \%$ in one level, excluding Chaetoceros spp. resting spores. The stratigraphic plotting of the data (Fig. 4) was carried out using Tilia 2.0.38 (Grimm 1987).

\subsection{Stable carbon and nitrogen isotopes}

For the stable carbon $\left(\delta^{13} \mathrm{C}\right)$ and nitrogen $\left(\delta^{15} \mathrm{~N}\right)$ isotope measurements, about $5 \mathrm{mg}$ of ground dry sediment was weighed in open Ag capsules. After being transferred to a glass tray and placed on a 
hotplate, $10 \mu \mathrm{l}$ of distilled water was added to each capsule to moisten the sediments. After moistening, $10 \mu \mathrm{l}$ of $2 \mathrm{~N} \mathrm{HCl}$ was added and the temperature was slowly increased to $50^{\circ} \mathrm{C}$. An additional $20 \mu \mathrm{l}$ $\mathrm{HCl}$ was added and there was no detectable reaction observed using a binocular microscope. The $\mathrm{Ag}$ capsules containing the samples were then wrapped in Sn capsules to improve combustion efficiency. $\delta^{13} \mathrm{C}$ and $\delta^{15} \mathrm{~N}$ were determined by gas-source isotope-ratio mass spectrometry after thermal combustion. The results of the carbon and nitrogen isotope measurements were normalized to the $\mathrm{V}$ PDB (Vienna PeeDee Belemnite) and atmospheric N, $\delta(\%)=\left[\left(\mathrm{R}_{\text {sample }}-\mathrm{R}_{\text {standard }}\right) / \mathrm{R}_{\text {standard }}\right] \times 1000$. The $\delta^{13} \mathrm{C}$ values were corrected for the time-dependent depletion in atmospheric $\delta^{13} \mathrm{C}$ due to fossil-fuel burning since $1840 \mathrm{CE}$, following the equation in Verburg (2007). The stable isotope measurements were carried out in the Department of Biology, Lund University.

\subsection{Element analysis with ICP-OES}

To determine total concentrations of the trace elements copper $(\mathrm{Cu})$, zinc $(\mathrm{Zn})$ and lead $(\mathrm{Pb})$, and the major element aluminium ( $\mathrm{Al})$ in the sediment, $0.125 \mathrm{~g}$ of sample from selected depths was dissolved in $2.5 \mathrm{ml}$ of $40 \% \mathrm{HF}, 2.5 \mathrm{ml}$ of a $72 \% \mathrm{HClO}_{4}$, and $65 \% \mathrm{HNO}_{3}$ mixture (volumetric ratio 3:2) in closed Teflon bombs at $90^{\circ} \mathrm{C}$, followed by evaporation of the solution and redissolution of the remaining gel in $1 \mathrm{M} \mathrm{HNO}_{3}$. Concentrations of various elements in the $\mathrm{HNO}_{3}$ solutions were analyzed with Inductively Coupled Plasma Optical Emission Spectroscopy (ICP-OES) at the Department of Earth Sciences, Utrecht University.

\subsection{Redundancy analysis (RDA)}

To assess the effect different forcing factors may have had on the biogeochemistry and on the diatom assemblage in Gåsfjärden, Redundancy Analyses (RDA), a type of constrained ordination analysis, were carried out using CANOCO (Ter Braak and Smilauer 2002). RDA was selected as the preferred ordination type as preliminary DCCA (Detrended Canonical Correspondence Analyses) showed that the gradient length in the dataset were short, $<2$ SD units (Ter Braak and Smilauer, 2002).

As potential forcing factors or explanatory variables in the RDA, we used the percentage land cover of deciduous and coniferous woodland, cropland, grassland, and wetland (estimated as the cover of Calluna and Cyperaceae) from the REVEALS reconstruction as well as a mean annual temperature simulation for the Baltic Sea region (Schimanke et al. 2012) and a sea surface temperature reconstruction for the North Atlantic based on $\delta^{18} \mathrm{O}$ measured on planktonic foraminifera (Sejrup et al. 2010) (also shown in Fig. 9). Historic and prehistoric land use changes have been shown to affect diatom assemblages (Bradshaw et al. 2005, 2006) and sediment geochemistry (Søe et al., 2016) in lakes, through nutrient inputs from increased soil erosion and animal manure. It has also been suggested that such eutrophication due to past land use has had an effect on the Baltic Sea (e.g. Zillén 
and Conley, 2010). Several palaeolimnological studies have demonstrated that diatom assemblages are affected directly or indirectly by temperature (e.g. review by Anderson, 2000).

Eighteen time slices between 900 and 2010 CE were created for the land cover data. Each time slice for the periods $900-1500 \mathrm{CE}, 1500-1950 \mathrm{CE}$, and 1950-2010 CE covered 100, 50, and 10-20 years, respectively. In the analysis of the diatom assemblages, relative percentage values of diatom species were used as the response variables. For each diatom sample or geochemical data point $\left(\mathrm{C}_{\text {org }} \mathrm{MAR}\right.$, $\mathrm{C}_{\text {org }} / \mathrm{N}_{\text {tot }}$, BSi MAR, $\delta^{13} \mathrm{C}$, and $\delta^{15} \mathrm{~N}$ ), the REVEALS reconstruction for the corresponding time slice was applied. The climate records, covering the last millennium, were smoothed using an 11-year window and were interpolated to the ages of the diatom and the geochemical samples, respectively. The percentage values for diatoms and land cover were square root transformed for the analysis.

To identify the environmental variables which had most explanatory power in relation to the diatom and geochemical data, we used manual forward selection. This consists of first testing each environmental variable separately, selecting the one which explains most of the variability in the response variables, and then testing the remaining potential drivers to see how much additional variation they explain in combination with the first selected variable, and so on. Monte Carlo permutation tests were used to assess the significance of the relationship, and parameter selection stopped when further additional parameters were not significant at the 5\% level. We then checked the selected set of environmental variables for co-linearity by the resulting variance inflation factors, which were all less than two, indicating that there were no collinearity problems in the selected models (Zuur et al., 2010). The potential environmental drivers which were not selected in the forward selection procedure were included as passive variables in the analysis, so that they can be plotted in the RDA triplots but do not affect the ordination and the statistical relationship between the selected drivers and diatoms and geochemical data respectively.

\section{Results}

\subsection{Pollen analysis of Lake Storsjön sediment and land cover reconstruction}

Over the study period, 77 pollen samples were counted and 87 pollen and spore types were identified. The pollen counts for the 23 pollen types used in the REVEALS analysis (Fig. 3) accounted for more than $96 \%$ of the total pollen sum in every sample. During 900-1000 CE (pollen assemblage zone-PAZ 1), woodlands covered more than $80 \%$ of the region, and conifers were slightly more abundant than deciduous trees, accounting for $c .45 \%$ and $37 \%$ of the woodland, respectively. Open land covered more than $10 \%$ of the landscape, of which grassland $(9 \%)$ was the major land use and cropland covered 2.5\%. In the transition to the period 1000-1400 CE (PAZ 2), coniferous woodland cover increased by a third, to more than $60 \%$ of the area, while the cover of deciduous trees declined, in particular for Corylus (hazel) and Carpinus (hornbeam), later also Quercus (oak), Tilia (lime), and 
Ulmus (elm). These changes are largely due to the expansion of Picea (spruce) from the north at this time, replacing deciduous trees. The cover of Pinus (pine), which probably occupied areas with sandy soils or thin soil layers, as it does today in the region, remained largely unchanged. The spatial extent of agricultural land use in the region remained the same as during PAZ 1.

\section{FIG. 3}

During the period 1400-1800 CE, (PAZ 3), there was an opening up of the landscape, where the grassland cover increased from less than 10 to $15 \%$ of the area, especially due to an increase in Poaceae (grasses) and in Juniperus (juniper), which is a characteristic shrub on pastures in southern Sweden. The abundance of Calluna (heather) and Cyperaceae (sedges) also increased during these centuries, reflecting an expansion of treeless wetlands in the region. This expansion could in part be related to a shift to a cooler, wetter climate during the LIA, although it may also have been a result of increased grazing and mowing, with these practices expanding into wetland areas. The area of cropland doubled to $5 \%$ during this period, with Secale (rye) covering $0.2-0.4 \%$ of the area, while the cover of other cereals was higher, up to $4.5 \%$, but seems to be quite variable during the period, with minima in the early 16th and late 17th centuries. The wooded part of the landscape was dominated by conifers, while the cover of deciduous tree species was low, and several species (e.g. Alnus (alder), Quercus, and Tilia) decreased in abundance during these centuries.

From the late 18th century, and especially within 1800-1950 CE (PAZ 4), cropland cover doubled, and grassland cover increased by three quarters. There was a sharp decline of woodland cover by about one fifth (to 55\% conifers and 10\% deciduous tree cover). Open land covered more than a quarter of the landscape of which grassland was the major land use represented by Poaceae (13-16\%) and Juniperus (5-6\%) while cropland represented by Cerealia (4-8\%) and Secale $(0.7-2 \%)$. The cover of the wetland taxa Calluna and Cyperaceae was reduced by more than half (from 9 to 4\%) during this period, probably as a result of ditching and drainage of wetlands, which took place at a very large scale throughout Sweden in the 19th century (Myrdal and Morell 2011).

After 1950 CE (PAZ 5), woodland cover expanded, and planted Picea covered 50\% of the region as a result of modern forestry practices. Many of the trees were probably planted during the early 20th century, as it takes approximately 40 years for Picea to reach flowering age, and hence increase in the pollen diagrams (Matthias et al. 2012). In the transition from traditional to modern agricultural practices, the area used for grazing decreased, and the near total abandonment of mowing lead to a reduced cover of Poaceae and Juniperus. Calluna and Cyperaceae continue to decrease as a result of continuous drainage of the landscape. Cropland cover was approximately halved (from $c .10$ to 5\%) of which the cover of Secale reached its maximum of $2.3 \%$ in the beginning of this period, but then dropped to less than $1 \%$. 


\subsection{Changes in the diatom stratigraphy of Gåsfjärden}

In total, 121 diatom taxa were identified and 33 taxa occurred with more than $2 \%$ in at least one level. The relative abundance of these taxa, divided into benthic and pelagic taxa and plotted in order of first appearance, are shown in Fig. 4. The diatom assemblage is dominated by benthic taxa throughout the core. Based on the cluster analysis, the stratigraphy is divided into three diatom assemblage zones (DAZ 1-3). The DCA axis 1 explains $20.5 \%$ of the variance and shows an increased taxa turnover from about $1900 \mathrm{CE}$. The diatom assemblage zones, DAZ 1-3, are described as follows:

DAZ 1 (925-1210 CE) was dominated by the epipsammic Opephora mutabilis together with the epiphytes Epithemia spp., Rhoicosphenia curvata, Cocconeis scutellum, Tabularia fasciculata and Melosira lineata. Pseudopodosira westii fo. parva was abundant. DAZ 1 was also characterized by a maximum occurrence of the pelagic taxa Aulacoseira islandica and Skeletonema costatum. The pelagic taxa in this zone constitute $c .10-11 \%$.

DAZ 2 (1210-1860 CE) was characterized by a dominance of the same species as in DAZ 1. Pelagic taxa decreased in this zone to about 3-8\% and consisted mainly of Pauliella taeniata and Aulacoseira subarctica. In this zone, S. costatum was not present and the relative abundance of $A$. islandica decreased. Benthic taxa that showed maximum abundances include Mastogloia smithii, Amphora pediculus, Ctenophora pulchella, Melosira moniliformis, Caloneis hyalina, Diploneis elliptica and Cocconeis neothumensis. Cocconeis scutellum decreased throughout this zone. The relative abundance of $O$. mutabilis was generally lower in DAZ 2 than in DAZ 1.

DAZ 3 (1860-2010 CE) showed a gradual shift towards an assemblage with a higher abundance of pelagic taxa, which increased from $17 \%$ to $30 \%$ in the uppermost sample. Cyclotella choctawhatcheeana appeared for the first time in the third sample from the top, which corresponds to about 1940 CE. Thalassiosira baltica and Thalassiosira levanderi increased in the three top samples. The sharp increase of $P$. taeniata in the topmost sample could be a preservation bias since this species is lightly silicified. The benthic freshwater species Martyana martyi also increased in this uppermost part of the core, which contributed to the increase of freshwater taxa in this zone. Chaetoceros spp. resting spores showed an increase until $1300 \mathrm{CE}$ followed by a decline from around $1500 \mathrm{CE}$. This decline continued until the end of the 19th century when they increased until the core top. The abundances of Ebria tripartita were relatively high around $1100 \mathrm{CE}$, during 1400-1650 CE and in the very top sample.

\section{FIG. 4}


The depth profiles of geochemical proxies of the Gåsfjärden sediments $\left(\mathrm{C}_{\mathrm{org}}, \mathrm{C}_{\mathrm{org}} \mathrm{MAR}, \mathrm{C}_{\mathrm{org}} / \mathrm{N}_{\mathrm{tot}}, \mathrm{BSi}\right.$, BSI MAR, $\delta^{13} \mathrm{C}$, and $\left.\delta^{15} \mathrm{~N}\right)$ are summarized in Fig. 5. $\mathrm{C}_{\text {org }}$ values were relatively high (8.5-9\%) between 900 and $1250 \mathrm{CE}$ but declined from 8 to $6 \%$ between 1250 and $1900 \mathrm{CE}$. The $\mathrm{C}_{\text {org }} \mathrm{MAR}$ demonstrated little variability throughout the record expect between 1450 and 1600 CE when an increase was noted. A rapid increase in $\mathrm{C}_{\text {org }}$ content was recorded between 1950 and $2010 \mathrm{CE}$, which was also noted in the $\mathrm{C}_{\text {org }}$ MAR data. The BSi values decreased from 16 to $10 \%$ during $900-1200 \mathrm{CE}$ and subsequently increased to $15 \%$ at $1450 \mathrm{CE}$. The BSi values declined during 1450-1900 CE and were lower than $8 \%$ during 1900-2010 CE. The BSi MAR record followed the general pattern of BSI record except less pronounced variability. As for the $\mathrm{C}_{\text {org }}$ MAR data, the BSi MAR record had higher values between 1450 and $\sim 1600 \mathrm{CE}$ and demonstrated a large increase for the uppermost samples. The $\mathrm{C}_{\text {org }} / \mathrm{N}_{\text {tot }}$ values ranged between 7 and 8.5 through the whole record with generally higher values after $1350 \mathrm{CE}$ than before. The $\delta^{15} \mathrm{~N}$ values $(2-4.2 \%$ ) were generally higher and more stable during 900-1300 CE than 1300-1700 CE (Fig. 5). An increase of $\delta^{15} \mathrm{~N}$ from 2 to $3.4 \%$ was recorded from 1700 to $1900 \mathrm{CE}$. Between 1900 and $1990 \mathrm{CE}$, the $\delta^{15} \mathrm{~N}$ values exhibited little changes. The highest value of $\delta^{15} \mathrm{~N}\left(4.2 \%\right.$ ) was observed in the surface sediments. The $\delta^{13} \mathrm{C}$ values varied between -24 and 21\%o, with relatively high values observed during 900-1300 CE and after $1650 \mathrm{CE}$ (Fig. 5).

\section{FIG. 5}

Trace metals copper $(\mathrm{Cu})$, zinc $(\mathrm{Zn})$, and lead $(\mathrm{Pb})$ were normalized to aluminium $(\mathrm{Al})$ and show distinct trends throughout the record (Fig. 6). All these metals are more enriched in sediments at the present day than at the base of the record $(800 \mathrm{CE})$ but the evolution of their enrichments contrasts markedly. $\mathrm{Pb} / \mathrm{Al}$ increased steadily throughout the record towards a maximum in the late 20th century. $\mathrm{Cu} / \mathrm{Al}$ was relatively low and stable until $1400 \mathrm{CE}$, after which values increased with several distinct peaks towards the present day. Two major peaks in the $\mathrm{Cu} / \mathrm{Al}$ record coincide with intervals of active $\mathrm{Cu}$ mining in the catchment of Gåsfjärden (grey bars in Fig. 6) (Hermansson 1966). Finally, Zn/Al was relatively low and stable until c. $1850 \mathrm{CE}$, after which a strong increase was observed towards a peak in the late 20 th century.

\section{FIG. 6}

\subsection{RDA analysis}

The forward selection in the RDA analysis of the diatom data (Fig. 7ab) indicates that for the diatom assemblage of Gåsfjärden, the cover of grassland had the strongest explanatory power among the factors tested, explaining $23.9 \%(\mathrm{p}=0.001)$ of the variations in the diatom data. After accounting for grassland, the cover of wetland explains an additional $10.2 \%(\mathrm{p}=0.008)$ of the variation. The North Atlantic climate reconstruction and the cover of deciduous woodland explain an additional $8.9 \%$ 
( $\mathrm{p}=0.013)$ and $7.4 \%(\mathrm{p}=0.024)$, respectively. Deciduous woodland cover is negatively correlated with grassland cover, as seen in Fig. 7ab, but the forward selection analysis still indicates that the residual variability in deciduous tree cover has a secular correlation with the diatom assemblage. This may be linked to the long-term change in the forests of the region from mixed deciduous to the predominance of coniferous trees, probably affecting the water chemistry, including the $\mathrm{pH}$. Changes in sample scores from $c .1000$ to $1750 \mathrm{CE}$ are most strongly associated with the increase in grassland and decline of deciduous woodland, but are also affected by variations in wetland cover and by climate variability, as recorded in the North Atlantic climate proxy data. The expansion and following decline in grassland, the marked decrease of wetland, and increased temperature are the major explanatory factors for the variation in diatom assemblage from $1800 \mathrm{CE}$ until today.

Mean grassland cover was also the forcing factor explaining most of the variation in the RDA for the Gåsfjärden geochemical data (Fig. 7c), accounting for $24.2 \%(\mathrm{p}=0.004)$. The second variable selected was wetland cover, explaining an additional $17.9 \%$ ( $\mathrm{p}=0.007)$. After accounting for these two factors, no other variables had significant additional explanatory power. The RDA triplot indicates that the $\mathrm{C} / \mathrm{N}$ ratio, and to a lesser degree $\delta^{15} \mathrm{~N}$, are correlated with grassland cover along the first axis, probably reflecting increased influx of terrestrial organic carbon, and increased productivity in response to nutrient inflow resulting from forest clearance over time (Fig, 7c). The accumulation rate of biogenic silica on the other hand is negatively correlated to grassland cover, possibly reflecting a shift in dominance from diatoms to other algal groups with increased nutrient availability. Meanwhile on the second axis, the accumulation rate of organic carbon is negatively correlated with wetland cover while $\delta^{13} \mathrm{C}$ is positively correlated. $\delta^{15} \mathrm{~N}$ also shows a minor negative correlation with wetland cover.

\section{FIG. 7}

\section{Discussion}

\subsection{Human impacts on a coastal environment}

Our results suggest that land use changes in the catchment of Gåsfjärden are important drivers of the observed variations in diatom composition as well as for the geochemical variables in the inlet over the last 1000 years, while at the same time, climate variability has also played a role (Fig. 7). The fastest changes are seen over the recent decades, after the introduction of industrial agriculture and artificial fertilizers, but even on the longer time scale of centuries, variations in the extent of land use, and associated erosion, have had an impact on the environment in the inlet. In general, the geochemical proxies indicate that the source of organic matter in the Gåsfjärden sediments is 
predominantly from autochthonous aquatic production, based on a biplot of $\mathrm{C}_{\mathrm{org}} / \mathrm{N}_{\text {tot }}$ and $\delta^{13} \mathrm{C}$ (Fig. 8, further discussion in Ning et al. 2016a). However, land use change may have altered the direct input of allochthonous organic material over time, as evidenced by the slight changes in $C_{\text {org }} / N_{\text {tot }}$ correlated with grassland cover in the RDA. Land use change likely also altered nutrient inputs, as suggested by the impact of grassland and wetland cover, for example, on $\delta^{15} \mathrm{~N}$. The variable diatom assemblages are an expression of these changing nutrient inputs, combined with background climate variations. Finally, elevated trace metal contents in the uppermost part of the sedimentary record reflect the intensification of anthropogenic activities in the region during recent centuries, associated with the industrialization process. In the following, we will discuss these various anthropogenic signals over the last few centuries in the Gåsfjärden sedimentary record in more detail, followed by a discussion of the impact of climate in section 5.2.

\section{FIG. 8}

\subsubsection{Changes in diatom assemblage}

Diatoms that live attached to plants or macroalgae, epiphytes, constitute a large portion of the benthic diatom population and are dependent on the distribution of their substrate, i.e. the sea grasses and macroalgae on which they grow. Increased phytoplankton growth and/or dissolved organic carbon (DOC) in the water column lead to decreased water transparency (Rosén et al. 2009), and will result in a decline in macrophytes habitat (Kautsky et al. 1986). Consequently, a decrease in epiphytic diatoms due to the loss of habitat and an increased production of pelagic taxa would increase the pelagic to benthic ratio (P/B ratio) in the sediment record. In the open Baltic Sea average secchi depth decreased c. $0.05 \mathrm{~m} \mathrm{yr}^{-1}$ between 1930s and 1990s due to eutrophication (Sanden and Håkansson 1996). Fleming-Lehtinen and Laamanen (2012) show a mean secchi depth decline from $8 \mathrm{~m}$ at 1905-1909 CE to $6 \mathrm{~m}$ at 2005-2009 CE in the Baltic Sea open waters. As a result of decreased water transparency, increased $\mathrm{P} / \mathrm{B}$ ratios in diatom records were found in the Baltic Sea coastal sediments, linked with agricultural expansion and/or intensification, urbanization, and industrial point sources starting between the 19th to mid-20th century depending on local conditions (Andrén 1999; Clarke et al. 2006; Ellegaard et al. 2006; Weckström 2006; Andrén et al. 2016).

In the Gåsfjärden record, increased P/B ratios after $1900 \mathrm{CE}$ indicate a decreased water transparency associated with eutrophication (Fig. 9). As Sweden changed gradually into an industrialized country since the early 1900s, cropland exhibited continuous decline and woodland expanded (Bragée et al. 2015). This afforestation process is also recorded from our land cover reconstruction (Fig. 4). Despite decreased cropland cover due to afforestation, the usage of artificial fertilizer increased in Sweden to support population growth, and nutrient input into Gåsfjärden likely increased after $1900 \mathrm{CE}$ as recorded in other regions (Gustafsson et al. 2012). 


\section{FIG. 9}

A common response to eutrophication is an increase in small pelagic diatom taxa (Andrén 1999; Weckström 2006; Tuovinen et al. 2010). Indeed, the results for Gåsfjärden showed increases in Cyclotella choctawhatcheeana and Thalassiosira levanderi since the 1940s. In brackish waters from Chesapeake Bay, C. choctawhatcheeana is also used as an eutrophication indicator (Cooper 1995). The small increase of Ebria tripartita in the very top of the core could be attributed to recent eutrophication (Korhola and Grönlund 1999), although the ecology of this species needs further study (Korhola and Grönlund 1999; Westman 2000).

Vegetative frustules of planktic Chaetoceros spp. are very lightly silicified and thereby rarely preserved in sediments but their heavily silicified resting spores can be found. High Chaetoceros spp. resting spore abundance has been used as an indication of high productivity in the open Baltic Sea (Andrén et al. 2000). Furthermore, the presence of Chaetoceros spp. resting spores indicates that the pelagic taxa potentially play an important part in the Gåsfjärden ecosystem and that the P/B ratio would change if resting spores would be included in the counts. Due to decreased erosion resulting from the afforestation of the landscape, the proportion of minerogenic material in the sediment decreased and the concentration of $\mathrm{C}_{\text {org }}$ increased after the 1950s. However, the BSi values were still low, suggesting that the overall diatom production was suppressed during the eutrophication process.

\subsubsection{Changes in sedimentary $\delta^{15} \mathrm{~N}$}

The land cover reconstruction for the Gåsfjärden catchment demonstrated that farming and grazing expanded in the 1800s, coinciding with the continuous increase of $\delta^{15} \mathrm{~N}$ values in Gåsfjärden sediment (Figs 7, 9). Urban waste water, agricultural runoff and animal manure typically display $\delta^{15} \mathrm{~N}$-dissolved inorganic nitrogen (DIN) values higher than 8\% (Teranes and Bernasconi 2000), whereas pristine rivers in northern Baltic Sea catchment have $\delta^{15} \mathrm{~N}$ values less than $3 \%$ (Voss et al. 2005). Enhanced anthropogenic nutrient input during the last decades have increased the $\delta^{15} \mathrm{~N}$ values in the primary production and subsequently led to sedimentary $\delta^{15} \mathrm{~N}$ values of $7.3 \pm 2.1 \%$ in the coastal regions of the southern and eastern Baltic Sea (Voss et al. 2005). Therefore, the elevated sedimentary $\delta^{15} \mathrm{~N}$ values since 1800s from this study are linked with increased population and agriculture activity, as also further indicated by the RDA analysis (Fig. 7c). The highest $\delta^{15} \mathrm{~N}$ value in our record is $4.2 \%$, which is fairly close to sedimentary $\delta^{15} \mathrm{~N}$ values in surface sediments in the present oligotrophic northern Baltic Sea (Voss et al. 2005) and in sediments dated prior to 1900 CE in Himmerfjärden Bay, south of Stockholm (Savage et al. 2010). From the 1820 s to the 1920 s, sedimentary $\delta^{15} \mathrm{~N}$ increased from $3.5 \%$ to $5.5 \%$ in Himmerfjärden Bay caused by increased population and enhanced agricultural activity 
(Savage et al. 2010). In Gåsfjärden, the increase over the same period is from c. 2.8 to $3.4 \%$. Since the 1960s agricultural use of nitrogen expanded and urban waste water increased, leading to an increase of $\delta^{15} \mathrm{~N}$ from 5.5 to $8.5 \%$ in Himmerfjärden Bay (Savage et al. 2010). The comparatively low values of $\delta^{15} \mathrm{~N}$ in Gåsfjärden (3.3-4.2\%o) indicates that the amount of nitrogen input from sewage treatment plants to Gåsfjärden is small, in particular compared to other Baltic Sea estuaries with considerable larger pollution.

The process of photosynthesis also causes $\delta^{15} \mathrm{~N}$ fractionation, as phytoplankton preferentially take up dissolved inorganic nitrogen (DIN) enriched with ${ }^{14} \mathrm{~N}$. However, assuming complete utilization of the DIN pool during a growth season, Rayleigh fractionation dictates that the net biomass $\delta^{15} \mathrm{~N}$ should be equal to that of the original DIN (Rolff 2000; Teranes and Bernasconi 2000; Jinglu et al. 2007). Hence, photosynthesis per se is not expected to influence our sediment $\delta^{15} \mathrm{~N}$ record. Another factor which could affect sedimentary $\delta^{15} \mathrm{~N}$ would be changes in the abundance of cyanobacteria, which derive $\mathrm{N}$ from atmospheric $\mathrm{N}_{2}$ and typically show light $\delta^{15} \mathrm{~N}$ values in their biomass (Carpenter et al., 1997). We discount a strong impact of cyanobacteria on our record, however, due to the fact that the $\delta^{15} \mathrm{~N}$ trend during the recent past (when cyanobacteria are most likely to have been abundant in Gåsfjärden) is towards heavier values.

\subsubsection{Trace metal pollution}

Significant enrichments of $\mathrm{Cu}, \mathrm{Zn}$, and $\mathrm{Pb}$ are observed in the sediments at Gåsfjärden (Fig. 6). The profiles of each of these elements are distinct from each other, and distinct from the profiles of $\mathrm{C}_{\text {org }}$ (Fig. 5) and sediment sulfur (S) content (not shown). Hence, the enrichments do not appear to be controlled by the accumulation rates of organic matter and sulfide minerals, which are the principal host phases for trace metals in sediments (Tribovillard et al. 2006). Therefore it is likely that the enrichments represent anthropogenic inputs of these metals form various sources. The pollution history of $\mathrm{Pb}$ in Swedish lakes has been extensively studied and shown to be regionally consistent (see Renberg et al. 2002). A generally increasing trend in sedimentary Pb content is observed over the last 1000 years, related to deposition from long-range atmospheric transport, the expanding exploitation of $\mathrm{Pb}$ ores in local and regional mining activities, and later emission of $\mathrm{Pb}$ from combustion. Higher $\mathrm{Pb}$ content in sediments is generally observed in southern Sweden due to a large contribution of atmospheric $\mathrm{Pb}$ deposition from sources in Western Europe. The Gåsfjärden record is consistent with these observations, showing an increasing trend in $\mathrm{Pb} / \mathrm{Al}$ over the sampled interval ( $800 \mathrm{CE}$-present) and generally high values throughout. The decrease at the top of the core may reflect controls on emissions and lead-free petrol, introduced in the 1970's and onwards. 
Periods of increased activity of the Solstad Gruva copper mine since c. 1750 are reflected as peaks in the $\mathrm{Cu} / \mathrm{Al}$ profiles at Gåsfjärden (Fig. 6, 9). The mine is located on the shore of the inlet, approximately $2 \mathrm{~km}$ from the sampling site (Fig. 1). Therefore it is likely that the mine acted as a strong local point source of $\mathrm{Cu}$ pollution. The principal $\mathrm{Cu}$ ore mined at Solstad was chalcopyrite $\left(\mathrm{CuFeS}_{2}\right)$ (Söderhielm and Sundblad 1996). Thus one likely mechanism of $\mathrm{Cu}$ transport to the study site may have been oxidation of chalcopyrite in tailings due to leaching by rainwater, followed by mobilization of $\mathrm{Cu}$ through complexation with dissolved organic carbon (DOC) (Lazerte et al. 1989). Flocculation of DOC along the salinity gradient of the inlet would then serve as a mechanism for $\mathrm{Cu}$ sedimentation as previously reported for iron (Boyle 1977). Alternatively, Cu-bearing solid particles may have been transported as aerosols by wind over the short distance from the mine to the study site.

$\mathrm{Zn} / \mathrm{Al}$ shows a distinct profile relative to $\mathrm{Pb} / \mathrm{Al}$ or $\mathrm{Cu} / \mathrm{Al}$, with strong enrichments only recorded in the 20th century. The use of $\mathrm{Zn}$ in manufacturing increased greatly in this period, and hence so did its potential as an environmental pollutant. $\mathrm{Zn}$ is particularly concentrated in road dust, where it accumulates from vehicle tire wear (Davis et al. 2001). Runoff then transports $\mathrm{Zn}$ from roads into aquatic systems, primarily during stormwater events, where it accumulates in sediments (Birch and Rochford, 2010). Although the catchment of Gåsfjärden remained comparatively rural during the 20th century, road construction was widespread during this period throughout Sweden. Hence, runoff from road surfaces is one likely source for the observed $\mathrm{Zn}$ enrichment in the sediments during the 20th century. Interestingly, a coincident enrichment is observed in $\mathrm{Cu} / \mathrm{Al}$, postdating the period of increased activity of the Solstad Gruva copper mine (Fig. 6). Cu is also known to be a major pollutant from road dust, sourced from vehicle brake emission (Davis et al. 2001). Therefore it is possible that the most recent peak in the $\mathrm{Cu} / \mathrm{Al}$ record also derives from road dust. Alternatively, the recent maxima in $\mathrm{Cu}$ and $\mathrm{Zn}$ may derive from antifouling paint on boat hulls (e.g. Haynes and Loong 2002, Ytreberg et al., 2010), as Gåsfjärden is a popular recreational sailing and motorboat destination in the summer months. We suggest a combination of these sources is the most likely explanation for the observed profiles.

\subsection{Possible climatic impacts on the Gåsfjärden sedimentary record}

Slightly higher diatom $\mathrm{P} / \mathrm{B}$ ratios were observed during 900-1200 $\mathrm{CE}$ (average $\mathrm{P} / \mathrm{B}=0.12$ ) compared to $1200-1800 \mathrm{CE}$ (average $\mathrm{P} / \mathrm{B}=0.07$ ) (Fig. 9). These two intervals overlap with two climatic intervals, the Medieval Climate Anomaly (MCA) and the Little Ice Age (LIA), respectively (Seppä et al. 2009). As land use showed little variation around $1200 \mathrm{CE}$, this variation in diatom P/B ratios might indicate some climate influence on the diatom assemblage, as also indicated by the RDA. Annual temperature was $1-2{ }^{\circ} \mathrm{C}$ higher during the MCA than during the LIA in northern Europe (Ljungqvist et al. 2012). Precipitation during the MCA is less well known, but the North Atlantic 
Oscillation exhibited a relatively more positive phase during the MCA than the LIA (Trouet et al. 2009; Ortega et al. 2015, Sejrup et al, 2010), which suggests higher precipitation in Scandinavia during the MCA (Hurrell 1995). Warmer and probably wetter conditions could have increased DOC and nutrient export into Gåsfjärden and stimulated phytoplankton production (Alheit et al. 2005), thereby contributing to a decline in water transparency and subsequent increase in P/B ratios during the MCA period.

Sedimentary $\delta^{15} \mathrm{~N}$ values are also slightly elevated during MCA with respect to LIA. This is not likely related to agricultural expansion and/or enhanced manure usage, as the pollen record indicates that land use intensity in our study region was low during the MCA period. Hence some climatic impact on the biogeochemical cycling of the inlet may have caused the higher $\delta^{15} \mathrm{~N}$ values.

Although increased cyanobacterial production was observed during the MCA in the open Baltic Sea (Struck et al. 2000; Funkey et al. 2014), this was apparently not the case in Gåsfjärden, otherwise $\delta^{15} \mathrm{~N}$ would be expected to shift to more negative values (see Section 5.1.2). Alternatively, higher $\delta^{15} \mathrm{~N}$ values may reflect increased rates of sedimentary denitrification (conversion of $\mathrm{NO}_{3}^{-}$to $\mathrm{N}_{2}$ ), as this process may enrich the residual DIN pool with ${ }^{15} \mathrm{~N}$ (Jähnke and Thamdrup 2013). This explanation, however, also remains speculative in our case, since Gåsfjärden sediments show little other evidence for intensified anaerobic conditions during the MCA (Ning et al. 2016a).

The colder conditions during the following LIA, reflected in the North Atlantic climate proxies, seem to be related to the maximum relative abundance of benthic diatom taxa (in DAZ 2), indicating reduced proportion planktic diatoms (shown as lower P/B ratios in Fig. 9), and increased water transparency. The slightly lower $\delta^{15} \mathrm{~N}$ values during the LIA compared to the MCA may also be a result of reduced primary productivity in the inlet. Overall, the environmental variables display larger variability during the LIA compared with the MCA, with variations in both land use and climatic proxies (Fig. 9), as well as in the isotope records and other chemical proxies from Gåsfjärden. Further, the RDA for the geochemical data highlights the negative correlation between wetland cover and the carbon isotopes and the organic carbon content. Wetland cover had its maximum distribution during the LIA suggesting higher precipitation (relative to evaporation) as a potential driver. The RDA indicates that the diatom assemblage in the period 1250-1750 responds to short term variations in both land use (along the first RDA axis) and climate (the second axis). After 1750, the diatom assemblage change becomes more unidirectional, responding to increasing nutrient inputs associated with expanding agriculture as well as to the warming and changes in NAO after the LIA.

Over the past century, increased precipitation together with the drainage of wetlands could have led to increased freshwater inflow to Gåsfjärden, and therefore decreased surface water salinity. The 
enhanced abundance of freshwater diatom taxa, mainly consisting of Martyana martyi and Aulacoseira islandica are therefore possibly related to the salinity decrease.

\section{Conclusions}

Coastal environments such as the Baltic coast have experienced large changes on ecosystem level as a result of human activities. We have used a pollen-based land use reconstruction from Lake Storsjön with multi-proxy analysis from the inlet Gåsfjärden to put recent environmental changes into a longterm perspective. This has resulted in an increased understanding of how land use changes and climate variability have affected this coastal environment over the last millennium and highlighted the very large environmental changes which have occurred over the last 100-200 years.

Prior to the $1800 \mathrm{~s}$, minor variations in the diatom assemblage and sedimentary geochemical record from Gåsfjärden were likely driven both by climatic variations and by changes in nutrient input related to land use change. The onset of eutrophication can be observed before the $1900 \mathrm{CE}$, mainly caused by intensified human activity such as an expanding agriculture, including increased grazing and wetland ditching. Continuous coastal ecosystem deterioration was observed from the early 1900s to present, as indicated by sharp increases in the diatom $\mathrm{P} / \mathrm{B}$ ratio and $\delta^{15} \mathrm{~N}$ values. The linkage between the enhanced land use and elevated $\delta^{15} \mathrm{~N}$ values suggests that long-term sedimentary $\delta^{15} \mathrm{~N}$ variation is caused by additional sources of the nitrogen.

We can conclude that anthropogenic activities in the 20th century, such as the widespread usage of fertilizer, have caused coastal ecosystem changes that are unprecedented during the last millennium.

\section{Acknowledgements}

We thank the captain and crew of R/V Ocean Surveyor for their help during sampling in Gåsfjärden. Conny Lenz, Vincent Kofman and Leo de Jong are thanked for their assistance with sediment sampling and lab analysis, Anupam Ghosh and Ants Aader for their help with fieldwork in Storsjön and Semjon Schimanke for providing the Baltic Sea temperature data. The project was funded by FORMAS Strong Research Environment: Managing Multiple Stressors in the Baltic Sea (217-2010-126). We also acknowledge funding from the Crafoord Foundation, the Royal Physiographic Society in Lund, the Netherlands Organization for Scientific Research (NWO Vidi 86405.004), the European Research Council (ERC Starting Grant \#278364) and the Foundation for Baltic and East European Studies (grant 1562/3.1.1/2013). 


\section{References}

Alheit, J., Möllmann, C., Dutz, J., Kornilovs, G., Loewe, P., Mohrholz, V. \& Wasmund, N. 2005: Synchronous ecological regime shifts in the central Baltic and the North Sea in the late 1980s. ICES Journal of Marine Science: Journal du Conseil 62, 1205-1215.

Andersen, J. H., Axe, P., Backer, H., Carstensen, J., Claussen, U., Fleming-Lehtinen, V., Järvinen, M., Kaartokallio, H., Knuuttila, S., Korpinen, S., Kubiliute, A., Laamanen, M., Lysiak-Pastuszak, E., Martin, G., Murray, C., Møhlenberg, F., Nausch, G., Norkko, A. \& Villnäs, A. 2011: Getting the measure of eutrophication in the Baltic Sea: towards improved assessment principles and methods. Biogeochemistry 106, 137-156.

Andersen, J. H., Carstensen, J., Conley, D. J., Dromph, K., Fleming-Lehtinen, V., Gustafsson, B. G., Josefson, A. B., Norkko, A., Villnäs, A. \& Murray, C. 2015: Long-term temporal and spatial trends in eutrophication status of the Baltic Sea. Biological Reviews.

Anderson, N.J., 2000. Miniview: Diatoms, temperature and climatic change. European Journal of Phycology 35, 307-314.

Andrén, E. 1999: Changes in the composition of the diatom flora during the last century indicate increased eutrophication of the Oder estuary, south-western Baltic Sea. Estuarine, Coastal and Shelf Science 48, 665-676.

Andrén, E., Andrén, T. \& Kunzendorf, H. 2000: Holocene history of the Baltic Sea as a background for assessing records of human impact in the sediments of the Gotland Basin. The Holocene $10,687-702$.

Andrén, E., Telford, R.J. \& Jonsson, P. 2016. Reconstructing the history of eutrophication and quantifying total nitrogen reference conditions in Bothnian Sea coastal waters. Estuarine, Coastal and Shelf Science. http://dx.doi.org/10.1016/j.ecss.2016.07.015

Appleby. P.G. \& Oldfield, F. 1978: The calculation of lead-210 dates assuming a constant rate of supply of unsupported ${ }^{210} \mathrm{~Pb}$ to the sediment. Catena $5,1-8$.

Åkesson, C., Nielsen, A.B., Broström, A., Persson, T., Gaillard, M.-J. \& Berglund, B.E. 2015: From landscape description to quantification: A new generation of reconstructions provides new perspectives on Holocene regional landscapes of SE Sweden. The Holocene 25, 178-193.

Battarbee, R. W. 1986: Diatom analysis. In Berglund, B. E. (ed.): Handbook of Holocene Palaeoecology and Palaeohydrology, 527-570 pp. Johan Wiley \& Sons Ltd., Chichester.

Battarbee, R. W., Anderson, N. J., Bennion, H., \& Simpson, G. L. (2012). Combining limnological and palaeolimnological data to disentangle the effects of nutrient pollution and climate change on lake ecosystems: problems and potential. Freshwater Biology, 57(10), 2091-2106.

Berglund, B. \& Ralska-Jasiewiczowa, M. 1986: Pollen analysis and pollen diagrams. In Berglund, B. (ed.): Handbook of Holocene palaeoecology and palaeohydrology, 455-484. John Wiley \& Sons, Chichester.

Beug, H. J. 2004: Leitfaden der Pollenbestimmung für Mitteleuropa und angrenzende Gebiete. Verlag Dr. Friedrich Pfeil, München.

Birch, G.F. and Rochford, L., 2010: Stormwater metal loading to a well-mixed/stratified estuary (Sydney Estuary, Australia) and management implications. Environmental Monitoring and Assessment 169, 531-551.

Blaauw, M. 2010: Methods and code for 'classical' age-modelling of radiocarbon sequences. Quaternary Geochronology 5, 512-518.

Boyle, E.A., Edmund, J.A. and Sholkovitz, E.R. 1977: The mechanism of iron removal in estuaries. Geochimica et Cosmochimica Acta 41, 1313-1324.

Bradshaw, E.G., Rasmussen, P., Odgaard, B.V., 2005. Mid-to late-Holocene land-use change and lake development at Dallund S0, Denmark: synthesis of multiproxy data, linking land and lake. The Holocene 2005 : 15, 1152-1162.

Bradshaw, E., Nielsen, A. B. \& Anderson, N. J. 2006: Using diatoms to assess the impacts of prehistoric, pre-industrial and modern land-use on Danish lakes. Regional Environmental Change 6, 17-24. 
Bragée, P., Mazier, F., Rosén, P., Fredh, D., Broström, A., Granéli, W. \& Hammarlund, D. 2015: Historical TOC concentration minima during peak sulfur deposition in two Swedish lakes. Biogeosciences, 12, 307-322.

Broström, A., Sugita, S. \& Gaillard, M.-J. 2004: Pollen productivity estimates for the reconstruction of past vegetation cover in the cultural landscape of southern Sweden. The Holocene 14, 368-381.

Carpenter, E. J., Harvey, H. R., Fry, B. \& Capone, D. G. 1997: Biogeochemical tracers of the marine cyanobacterium Trichodesmium. Deep Sea Research Part I: Oceanographic Research Papers 44, 27-38.

Carstensen, J., Andersen, J. H., Gustafsson, B. G. \& Conley, D. J. 2014: Deoxygenation of the Baltic Sea during the last century. Proceedings of the National Academy of Sciences 111, 5628-5633.

Clarke, A. L., Weckström, K., Conley, D. J., Anderson, N. J., Adser, F., Andrén, E., de Jonge, V. N., Ellegaard, M., Juggins, S., Kauppila, P., Korhola, A., Reuss, N., Telford, R. J. \& Vaalgamaa, S. 2006: Long-term trends in eutrophication and nutrients in the coastal zone. Limnology and Oceanography 51, 385-397.

Conley, D. J., Björck, S., Bonsdorff, E., Carstensen, J., Destouni, G., Gustafsson, B. G., Hietanen, S., Kortekaas, M., Kuosa, H., Markus Meier, H. E., Müller-Karulis, B., Nordberg, K., Norkko, A., Nürnberg, G., Pitkänen, H., Rabalais, N. N., Rosenberg, R., Savchuk, O. P., Slomp, C. P., Voss, M., Wulff, F. \& Zillén, L. 2009: Hypoxia-related processes in the Baltic Sea. Environmental Science \& Technology 43, 3412-3420.

Conley, D. J., Carstensen, J., Aigars, J., Axe, P., Bonsdorff, E., Eremina, T., Haahti, B.-M., Humborg, C., Jonsson, P., Kotta, J., Lännegren, C., Larsson, U., Maximov, A., Medina, M. R., LysiakPastuszak, E., Remeikaitè-Nikienè, N., Walve, J., Wilhelms, S. \& Zillén, L. 2011: Hypoxia is increasing in the coastal zone of the Baltic Sea. Environmental Science \& Technology 45, 6777-6783.

Cooper, S. R. 1995: Diatoms in sediment cores from the mesohaline Chesapeake Bay, USA. Diatom Research 10, 39-89.

DeMaster, D. J. 1981: The supply and accumulation of silica in the marine environment. Geochimica et Cosmochimica Acta 45, 1715-1732.

Davis, A.P., Shokouhian, M. \& Ni, S. 2001: Loading estimates of lead, copper, cadmium, and zinc in urban runoff from specific sources. Chemosphere 44, 997-1009.

Dähnke, K. \& Thamdrup, B.: 2013: Nitrogen isotope dynamics and fractionation during sedimentary denitrification in Boknis Eck, Baltic Sea. Biogeosciences 10, 3079-3088.

Ellegaard, M., Clarke, A. L., Reuss, N., Drew, S., Weckström, K., Juggins, S., Anderson, N. J. \& Conley, D. J. 2006: Multi-proxy evidence of long-term changes in ecosystem structure in a Danish marine estuary, linked to increased nutrient loading. Estuarine, Coastal and Shelf Science 68, 567-578.

Elmgren, R. 2001: Understanding human impact on the Baltic ecosystem: Changing views in recent decades. AMBIO 30, 222-231.

Emanuelsson, U. 2009: The rural landscapes of Europe. How man has shaped European nature. The Swedish Research Council Formas. 383 pp.

Faegri, K. \& Iversen, J. 1989: Textbook of pollen analysis (4th edn by Faegri, K., Kaland, PE \& Krzywinski, K.). Wiley, Chichester.

Fleming-Lehtinen, V. \& Laamanen, M. 2012: Long-term changes in Secchi depth and the role of phytoplankton in explaining light attenuation in the Baltic Sea. Estuarine, Coastal and Shelf Science 102-103, 1-10.

Fredh, D., Broström, A., Zillén, L., Mazier, F., Rundgren, M. \& Lagerås, P. 2012: Floristic diversity in the transition from traditional to modern land-use in southern Sweden AD 1800-2008. Vegetation History and Archaeobotany 21, 439-452.

Fritz, S. C. 1989: Lake Development and Limnological Response to Prehistoric and Historic Land-Use in Diss, Norfolk, U.K. Journal of Ecology 77, 182-202.

Funkey, C. P., Conley, D. J., Reuss, N. S., Humborg, C., Jilbert, T. \& Slomp, C. P. 2014: Hypoxia Sustains Cyanobacteria Blooms in the Baltic Sea. Environmental Science \& Technology 48, 2598-2602. 
Gadd, C. J. 2011: The agricultural revolution in Sweden 1700-1870. In: J. Myrdal and M. Morell (eds.): The Agrarian History of Sweden From 4000 BC to AD 2000. Nordic Academic press. $336 \mathrm{pp}$.

Gaillard, M. J., Dearing, J. A., El-Daoushy, F., Enell, M. \& Håkansson, H. 1991: A late Holocene record of land-use history, soil erosion, lake trophy and lake-level fluctuations at Bjäresjösjön (south Sweden). Journal of Paleolimnology 6, 51-81.

Grimm, E. C. 1987: CONISS: a FORTRAN 77 program for stratigraphically constrained cluster analysis by the method of incremental sum of squares. Computers \& Geosciences 13, 13-35.

Gustafsson, B. G., Schenk, F., Blenckner, T., Eilola, K., Meier, H. E. M., Müller-Karulis, B., Neumann, T., Ruoho-Airola, T., Savchuk, O. \& Zorita, E. 2012: Reconstructing the development of Baltic Sea eutrophication 1850-2006. AMBIO 41, 534-548.

Haynes, D. \& Loong, D. 2002: Antifoulant (butyltin and copper) concentrations in sediments from the Great Barrier Reef World Heritage Area, Australia. Environmental Pollution 120, 391-396.

HELCOM 2009: Eutrophication in the Baltic Sea-An integrated thematic assessment of the effects of nutrient enrichment and eutrophication in the Baltic Sea region Baltic Sea Environment Proceedings $115 B$.

Hellman, S., Gaillard, M.-J., Broström, A. \& Sugita, S. 2008: The REVEALS model, a new tool to estimate past regional plant abundance from pollen data in large lakes: validation in southern Sweden. Journal of Quaternary Science 23, 21-42.

Hermansson, W. 1966: Solstad koppargruva. Kalmar nations skriftserie 43, 18-51.

Hurrell, J. W. 1995: Decadal trends in the North Atlantic Oscillation: regional temperatures and precipitation. Science 269, 676-679.

Jinglu, W., Chengmin, H., Haiao, Z., Schleser, G. \& Battarbee, R. 2007: Sedimentary evidence for recent eutrophication in the northern basin of Lake Taihu, China: human impacts on a large shallow lake. Journal of Paleolimnology 38, 13-23.

Juggins, S. 2014: rioja: an R Package for the Analysis of Quaternary Science Data.

Kabel, K., Moros, M., Porsche, C., Neumann, T., Adolphi, F., Andersen, T.J., Siegel, H., Gerth, M., Leipe, T., Jansen, E., Sinninghe Damsté, J.S. 2012: Impact of climate change on the Baltic Sea ecosystem over the past 1,000 years. Nature Climate Change 2, 871-874.

Kautsky, N., Kautsky, H., Kautsky, U. \& Waern, M. 1986: Decreased depth penetration of Fucus vesiculosus (L.) since the 1940's indicates eutrophication of the Baltic Sea. Mar. Ecol. Prog. Ser 28, 1-8.

Korhola, A. \& Grönlund, T. 1999: Observations of Ebria tripartita (Schumann) Lemmermann in Baltic sediments. Journal of Paleolimnology 21, 1-8.

Krammer, K. \& Lange-Bertalot, H., 1986-1991. Bacillariophyceae. In Ettl, H., Gärtner, G. (teil 4), Gerloff, J., Heynig, H. \& Mollenhauer, D. (Eds) Süsswasserflora von Mitteleuropa, 1. Teil Naviculaceae, 876 pp. (1986), 2. Teil Bacillariaceae, Epithemiaceae, Surirellaceae, 596 pp (1988), 3. Teil Centrales, Fragilariaceae, Eunotiaceae, 576 pp. (1991), 4. Teil Achnantaceae, 437 pp. (1991) (Ettl, H., Gärtner, G. (teil 4), Gerloff, J., Heynig, H. \& Mollenhauer, D. eds). Gustav Fischer Verlag, Stuttgart, New York, Jena.

Lagerås, P. 1996: Vegetation and land-use in the Småland Uplands, southern Sweden, during the last 6000 years. Lundqua Thesis 36.

Lagerås, P. 2007: The Ecology of Expansion and Abandonment: Medieval and Post-Medieval Agriculture and Settlement in a Landscape Perspective. Riksantikvarieämbetet.

Lamb, A. L., Wilson, G. P. \& Leng, M. J. 2006: A review of coastal palaeoclimate and relative sealevel reconstructions using $\delta^{13} \mathrm{C}$ and $\mathrm{C} / \mathrm{N}$ ratios in organic material. Earth-Science Reviews 75 , 29-57.

Lazerte, B., Evans, D. and Grauds, P. 1989: Deposition and transport of trace metals in an acidified catchment of Central Ontario. Science of the Total Environment, 87-88, 209-221.

Legrand, C., Fridolfsson, E., Bertos-Fortis, M., Lindehoff, E., Larsson, P., Pinhassi, J. \& Andersson, A. 2015: Interannual variability of phyto-bacterioplankton biomass and production in coastal and offshore waters of the Baltic Sea. AMBIO 44, 427-438.

Ljungqvist, F. C., Krusic, P. J., Brattström, G. \& Sundqvist, H. S. 2012: Northern Hemisphere temperature patterns in the last 12 centuries. Clim. Past 8, 227-249. 
Matthias, I., Nielsen, A.B., Giesecke, T. 2012: Evaluating the effect of flowering age and forest structure on pollen productivity estimates. Vegetation History and Archaeobotany 21, 471-484

Mazier, F., Broström, A., Bragée, P., Fredh, D., Stenberg, L., Thiere, G., Sugita, S. \& Hammarlund, D. 2015: Two hundred years of land-use change in the South Swedish Uplands: comparison of historical map-based estimates with a pollen-based reconstruction using the landscape reconstruction algorithm. Vegetation History and Archaeobotany 24, 555-570.

Meyers, P. A. 1994: Preservation of elemental and isotopic source identification of sedimentary organic matter. Chemical Geology 114, 289-302.

Moore, P. D., Webb, J. A. \& Collison, M. E. 1991: Pollen analysis. Blackwell scientific publications.

Myrdal, J. \& Morell, M. 2011: The agrarian history of Sweden: from 4000 BC to AD 2000. Nordic Academic Press.

Nielsen, A. B. 2004: Modelling pollen sedimentation in Danish lakes at c.ad 1800: an attempt to validate the POLLSCAPE model. Journal of Biogeography 31, 1693-1709.

Nielsen, A. B. \& Odgaard, B. V. 2010: Quantitative landscape dynamics in Denmark through the last three millennia based on the Landscape Reconstruction Algorithm approach. Vegetation History and Archaeobotany 19, 375-387.

Ning, W., Ghosh, A., Jilbert, T., Slomp, C. P., Khan, M., Nyberg, J., Conley, D. J. \& Filipsson, H. L. 2016a: Evolving coastal character of a Baltic Sea inlet during the Holocene shoreline regression: impact on coastal zone hypoxia. Journal of Paleolimnology 55, 319-338.

Ning W., Tang J., Filipsson H. L. 2016b: Long-term coastal openness variation and its impact on sediment grain-size distribution: a case study from the Baltic Sea. Earth Surface Dynamics, http://dx.doi.org/10.5194/esurf-2016-24

Oksanen, J., Blanchet, F. G., Kindt, R., Legendre, P., Minchin, P. R., O'Hara, R., Simpson, G. L., Solymos, P., Stevens, M. H. H. \& Wagner, H. 2015: Package 'vegan'. Community ecology package, version, 2.2-1.

Ortega, P., Lehner, F., Swingedouw, D., Masson-Delmotte, V., Raible, C. C., Casado, M. \& Yiou, P. 2015: A model-tested North Atlantic Oscillation reconstruction for the past millennium. Nature $523,71-74$.

Pedersen, E.A. and Widgren, M. 2011. Agriculture in Sweden, 800 BC -AD 1000. In: J. Myrdal and M. Morell (eds.): The Agrarian History of Sweden From 4000 BC to AD 2000. Nordic Academic press. 336 pp.

Rabalais, N. N., Díaz, R. J., Levin, L. A., Turner, R. E., Gilbert, D. \& Zhang, J. 2010: Dynamics and distribution of natural and human-caused hypoxia. Biogeosciences 7, 585-619.

Renberg, I. 1991: The HON-Kajak sediment corer. Journal of Paleolimnology 6, 167-170.

Renberg, I., Brännvall, M. L., Bindler, R., \& Emteryd, O. 2002: Stable lead isotopes and lake sediments - a useful combination for the study of atmospheric lead pollution history. Science of the Total Environment, 292, 45-54.

Reed, D. C., Slomp, C. P. \& Gustafsson B. G. 2011: Sedimentary phosphorus dynamics and the evolution of bottom-water hypoxia: A coupled benthic-pelagic model of a coastal system. Limnology and Oceanography 56, 1075-1092.

Rolff, C. 2000: Seasonal variation in $\delta 13 \mathrm{C}$ and $\delta 15 \mathrm{~N}$ of size-fractionated plankton at a coastal station in the northern Baltic proper. Marine ecology. Progress series 203, 47-65.

Rosentau, A., Harff, J., Oja, T. \& Meyer, M. 2012: Postglacial rebound and relative sea level changes in the Baltic Sea since the Litorina transgression. Baltica 25, 113-120.

Rosén, P., Cunningham, L., Vonk, J. \& Karlssona, J. 2009: Effects of climate on organic carbon and the ratio of planktonic to benthic primary producers in a subarctic lake during the past 45 years. Limnology and Oceanography 54, 1723-1732.

Round, F. E., Crawford, R. M. \& Mann, D. G. 1990: The diatoms: biology \& morphology of the genera. Cambridge University Press.

Sanden, P. \& Håkansson, B. 1996: Long term trends in Secchi depth in the Baltic Sea. Limnology and Oceanography 41, 346-351.

Savage, C., Leavitt, P. R. \& Elmgren, R. 2010: Effects of land use, urbanization, and climate variability on coastal eutrophication in the Baltic Sea. Limnology and Oceanography 55, 1033. 
Schimanke, S., Meier, H. E. M., Kjellström, E., Strandberg, G. \& Hordoir, R. 2012: The climate in the Baltic Sea region during the last millennium simulated with a regional climate model. Clim. Past 8, 1419-1433.

Schrader, H. \& Gersonde, R. 1978: Diatoms and silicoflagellates. In al., R. W. e. (ed.): Utrecht Micropaleontology Bulletin 17, 129-176.

Sejrup, H. P., Lehman, S. J., Haflidason, H., Noone, D., Muscheler, R., Berstad, I. M. \& Andrews, J. T. 2010: Response of Norwegian Sea temperature to solar forcing since 1000 A.D. Journal of Geophysical Research, 115.

Seppä, H., Bjune, A., Telford, R., Birks, H. \& Veski, S. 2009: Last nine-thousand years of temperature variability in Northern Europe. Climate of the Past 5, 523-535.

SMHI 2003: Djupdata för havsområden 2003. Oceanografi report no 73. Norrköping ISSN 0283-7714

Snoeijs, P. et al. 1993-1998. In Intercalibration and distribution of diatom species in the Baltic Sea (Snoeijs, P., Vilbaste, S. (Vol. 2), Potapova, M. (Vol. 3), Kasperovičienè, J. (Vol. 4), Balashova, N. (Vol. 5), eds): Vol. 1, 129 pp. (1993), Vol. 2, 126 pp. (1994), Vol. 3, 126 pp. (1995), Vol. 4, 126 pp. (1996), Vol. 5, 144 pp. (1998). The Baltic Marine Biologists Publication No. 16 a-e. Opulus Press, Uppsala.

Söderhielm, J. \& Sundblad, K. 1996: The Solstad Cu- Co- Au mineralization and its relation to postSvecofennian regional shear zones in southeastern Sweden. GFF 118, 47-47.

Stephens, M., Ripa, M. \& Lundström, I. 2009: Synthesis of the bedrock geology in the Bergslagen region, Fennoscandian shield, south- central Sweden. 259 pp., Uppsala.

Struck, U., Emeis, K. C., Voss, M., Christiansen, C. \& Kunzendorf, H. 2000: Records of southern and central Baltic Sea eutrophication in $\delta^{13} \mathrm{C}$ and $\delta^{15} \mathrm{~N}$ of sedimentary organic matter. Marine Geology 164, 157-171.

Sugita, S. 2007: Theory of quantitative reconstruction of vegetation I: pollen from large sites REVEALS regional vegetation composition. The Holocene 17, 229-241.

Sugita, S., Gaillard, M.-J. \& Broström, A. 1999: Landscape openness and pollen records: a simulation approach. The Holocene 9, 409-421.

Søe, N.E., Odgaard, B.V., Nielsen, A.B., Olsen, J., Kristiansen, S.M., 2017. Late Holocene landscape development around a Roman Iron Age mass grave, Alken Enge, Denmark. Vegetation History and Archaeobotany. 26, 277-292.

Ter Braak, C. J. \& Smilauer, P. 2002: CANOCO reference manual and CanoDraw for Windows user's guide: software for canonical community ordination (version 4.5). www. canoco. com.

Teranes, J. L. \& Bernasconi, S. M. 2000: The record of nitrate utilization and productivity limitation provided by $\delta^{15} \mathrm{~N}$ values in lake organic matter-A study of sediment trap and core sediments from Baldeggersee, Switzerland. Limnology and Oceanography 45, 801-813.

Tribovillard, N., Algeo, T. J., Lyons, T., \& Riboulleau, A. 2006: Trace metals as paleoredox and paleoproductivity proxies: an update. Chemical Geology 232, 12-32.

Trouet, V., Esper, J., Graham, N. E., Baker, A., Scourse, J. D. \& Frank, D. C. 2009: Persistent Positive North Atlantic Oscillation Mode Dominated the Medieval Climate Anomaly. Science 324, 78 80 .

Tuovinen, N., Weckström, K. \& Virtasalo, J. J. 2010: Assessment of recent eutrophication and climate influence in the Archipelago Sea based on the subfossil diatom record. Journal of Paleolimnology 44, 95-108.

Vahtera, E., Conley, D. J., Gustafsson, B. G., Kuosa, H., Pitkänen, H., Savchuk, O. P., Tamminen, T., Viitasalo, M., Voss, M. \& Wasmund, N. 2007: Internal ecosystem feedbacks enhance nitrogen-fixing cyanobacteria blooms and complicate management in the Baltic Sea. AMBIO: A Journal of the Human Environment 36, 186-194.

Verardo, D. J., Froelich, P. N. \& McIntyre, A. 1990: Determination of organic carbon and nitrogen in marine sediments using the Carlo Erba NA-1500 Analyzer. Deep Sea Research Part A. Oceanographic Research Papers 37, 157-165.

Verburg, P. 2007: The need to correct for the Suess effect in the application of $\delta 13 \mathrm{C}$ in sediment of autotrophic Lake Tanganyika, as a productivity proxy in the Anthropocene. Journal of Paleolimnology 37, 591-602. 
Voss, M., Emeis, K. C., Hille, S., Neumann, T. \& Dippner, J. W. 2005: Nitrogen cycle of the Baltic Sea from an isotopic perspective. Global Biogeochemical Cycles 19.

Voss, M., Larsen, B., Leivuori, M. \& Vallius, H. 2000: Stable isotope signals of eutrophication in Baltic Sea sediments. Journal of Marine Systems 25, 287-298.

Weckström, K. 2006: Assessing recent eutrophication in coastal waters of the Gulf of Finland (Baltic Sea) using subfossil diatoms. Journal of Paleolimnology 35, 571-592.

Welinder, S. 2011: Early farming households 3900-800 BC. In: J. Myrdal and M. Morell (eds.): The Agrarian History of Sweden From 4000 BC to AD 2000. Nordic Academic press. 336 pp.

Westman, P. 2000: The siliceous microalgae Dictyocha speculum and Ebria tripartita as biomarkers and palaeoecological indicators in Holocene Baltic Sea sediments. GFF 122, 287-292.

Witkowski, A., Lange-Bertalot, H. \& Metzeltin, D., 2000. Diatom Flora of Marine Coasts 1 (LangeBertalot, H., ed.). Iconographia Diatomologica 7. A.R.G. Gantner Verlag, pp. 925.

Yasuhara, M., Hunt, G., Breitburg, D., Tsujimoto, A. \& Katsuki, K. 2012: Human-induced marine ecological degradation: micropaleontological perspectives. Ecology and Evolution 2, 3242 3268 .

Ytreberg, E., Karlsson, J., \& Eklund, B. 2010: Comparison of toxicity and release rates of $\mathrm{Cu}$ and $\mathrm{Zn}$ from anti-fouling paints leached in natural and artificial brackish seawater. Science of the Total Environment 408 (12), 2459-2466.

Zillén, L., Conley, D.J., Andrén, T., Andrén, E. \& Björck, S. 2008. Past occurrences of hypoxia in the Baltic Sea and the role of climate variability, environmental change and human impact. Earth Science Reviews 91, 77-92.

Zillén, L. \& Conley, D. J. 2010: Hypoxia and cyanobacteria blooms - are they really natural features of the late Holocene history of the Baltic Sea? Biogeosciences 7, 2567-2580.

Zonneveld, K. A. F., Chen, L., Elshanawany, R., Fischer, H. W., Hoins, M., Ibrahim, M. I., Pittauerova, D. \& Versteegh, G. J. M. 2012: The use of dinoflagellate cysts to separate human-induced from natural variability in the trophic state of the Po River discharge plume over the last two centuries. Marine Pollution Bulletin 64, 114-132.

Zuur, A. F., Ieno, E. N. and Elphick, C. S. 2010: A protocol for data exploration to avoid common statistical problems. Methods in Ecology and Evolution 1, 3-14. 


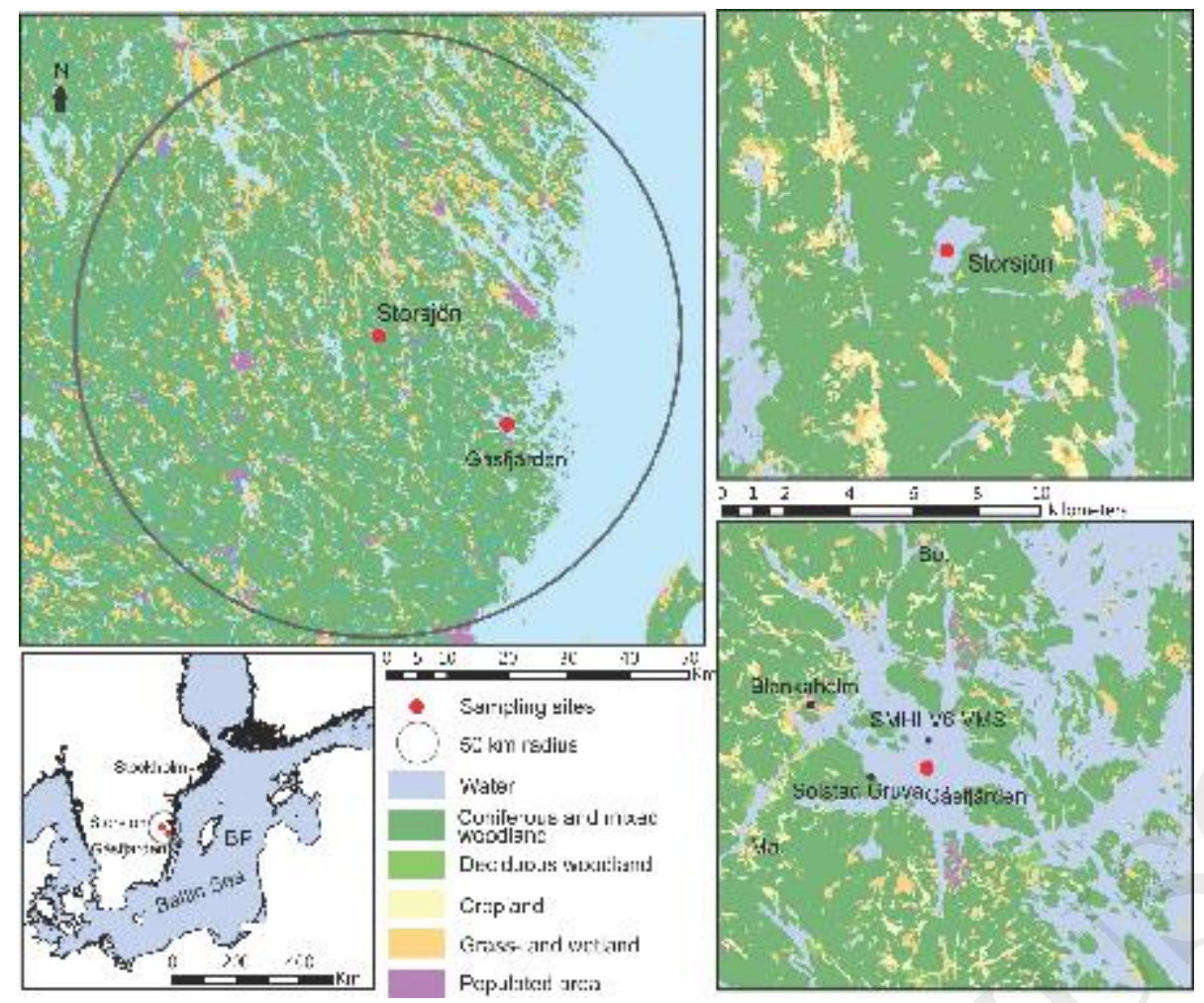



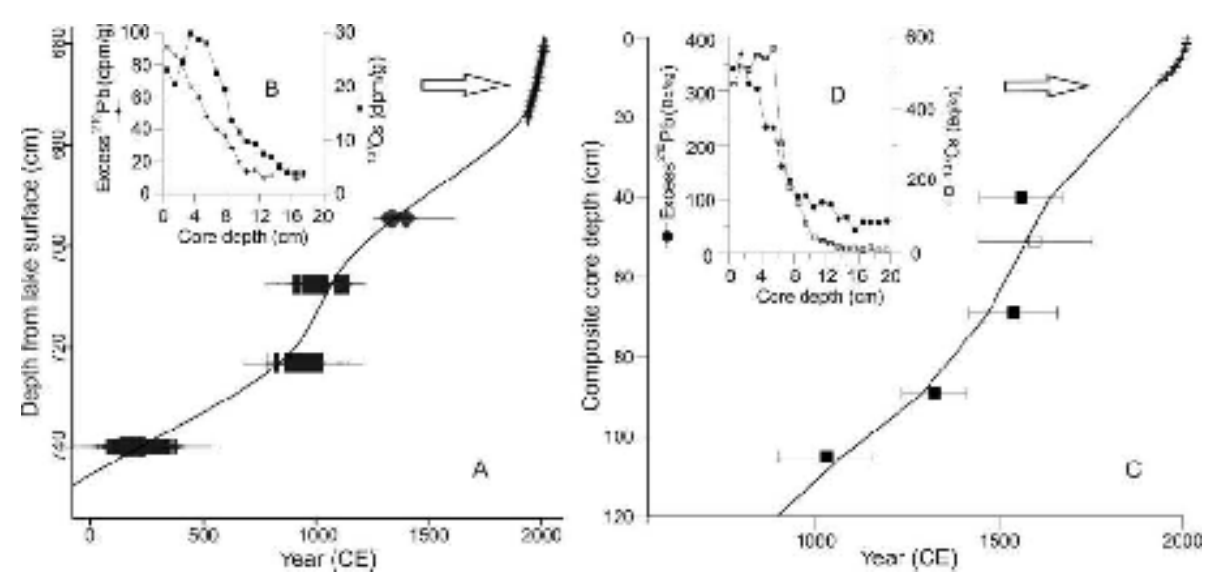


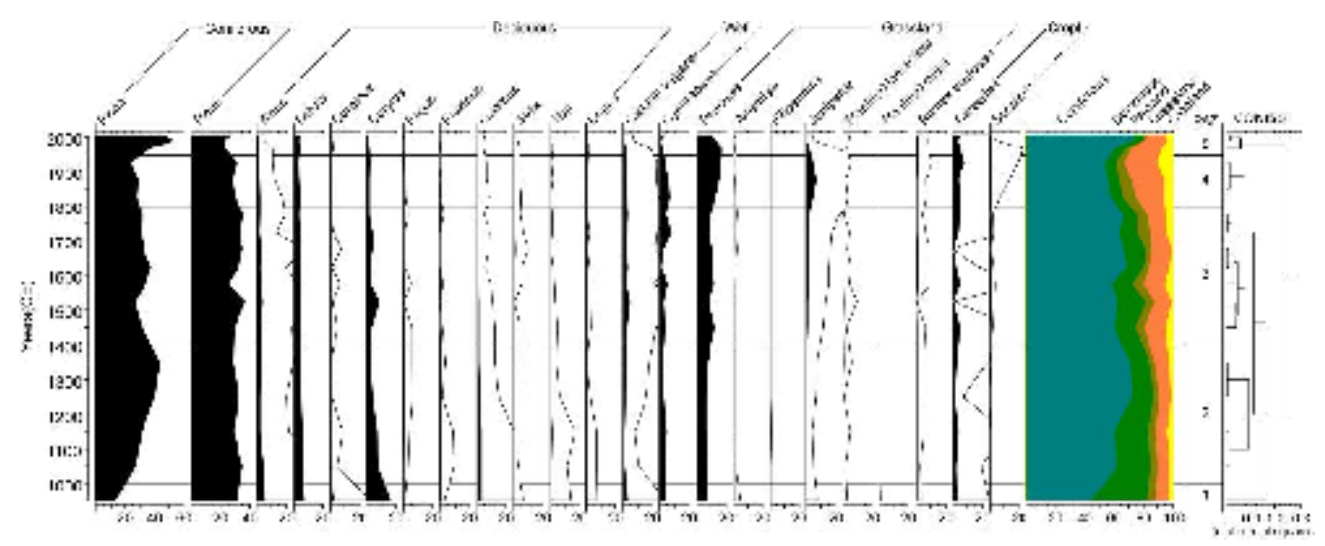




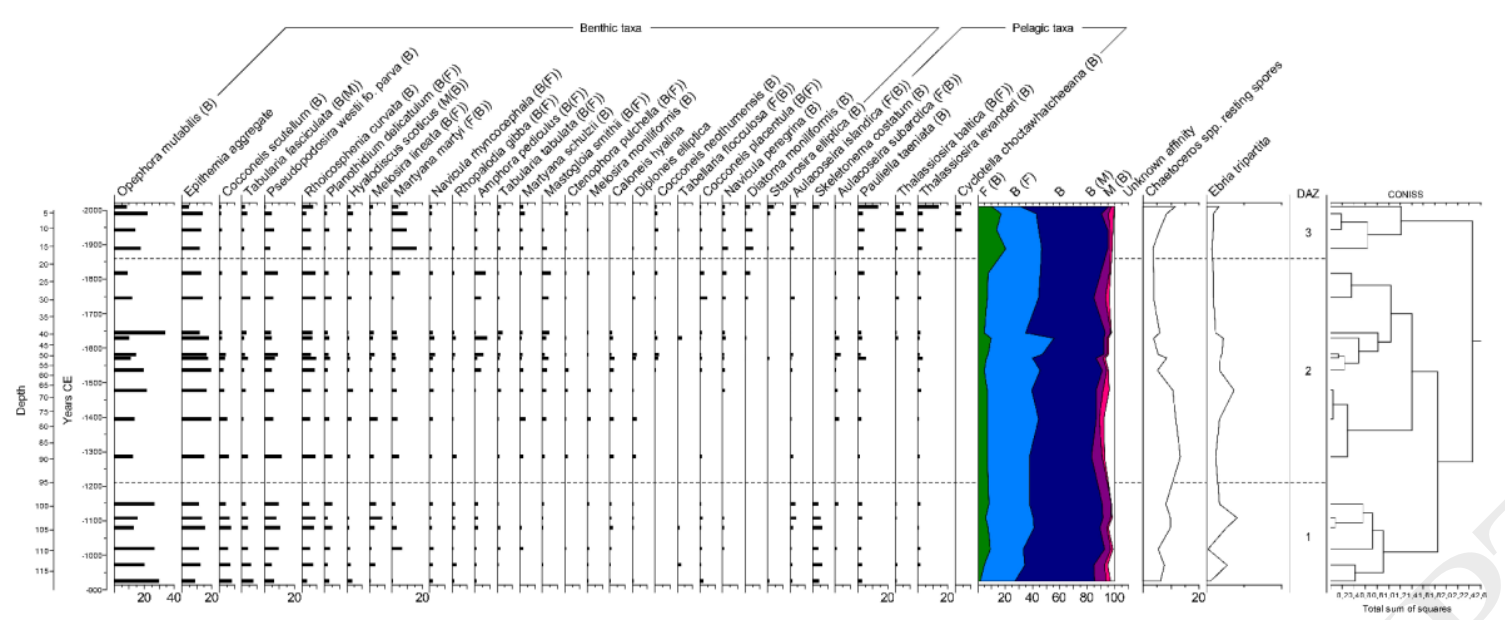




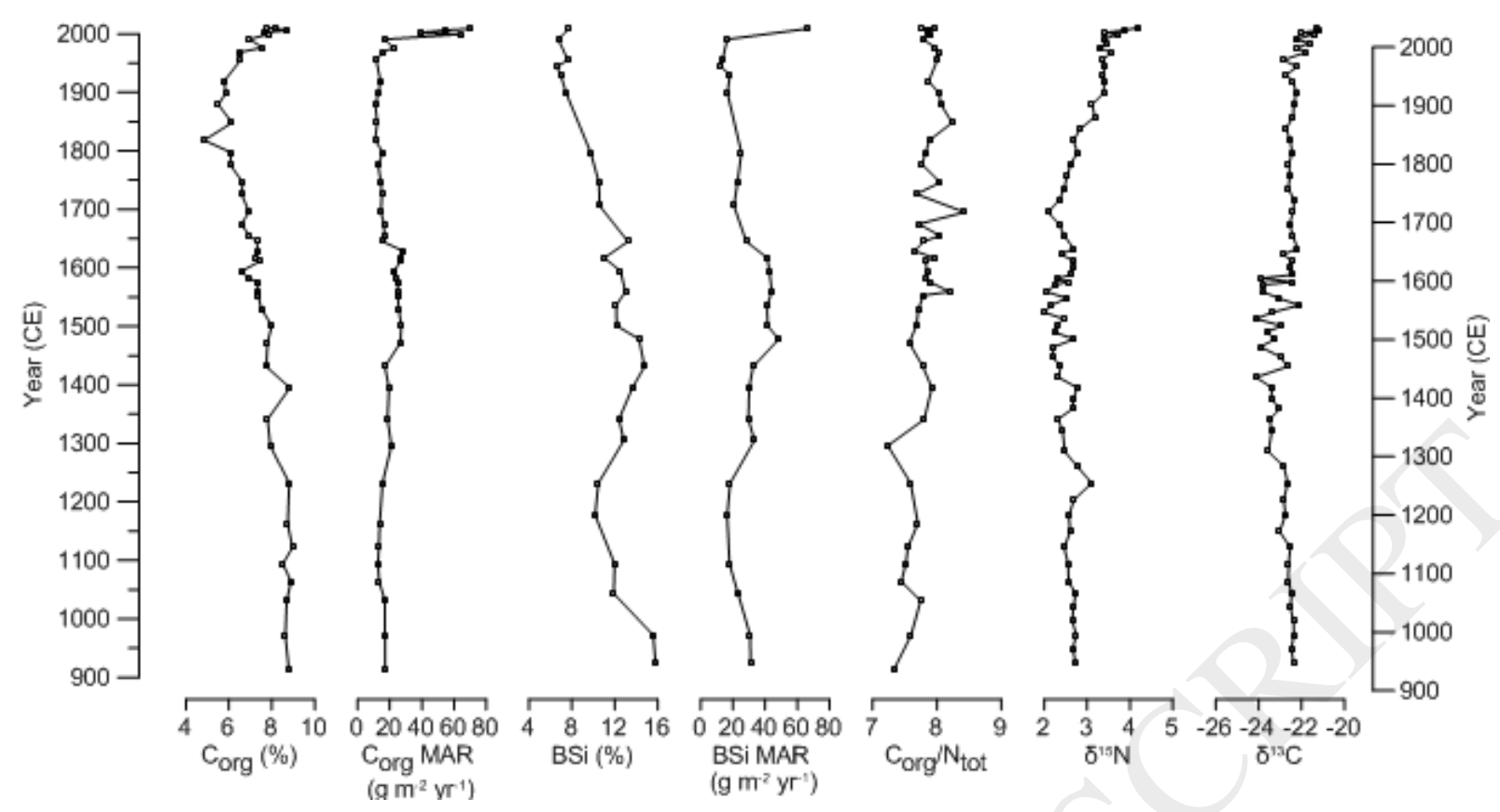




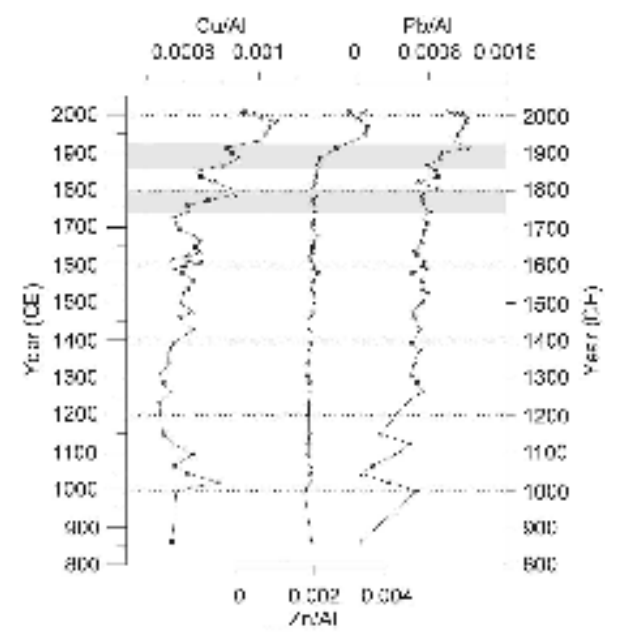



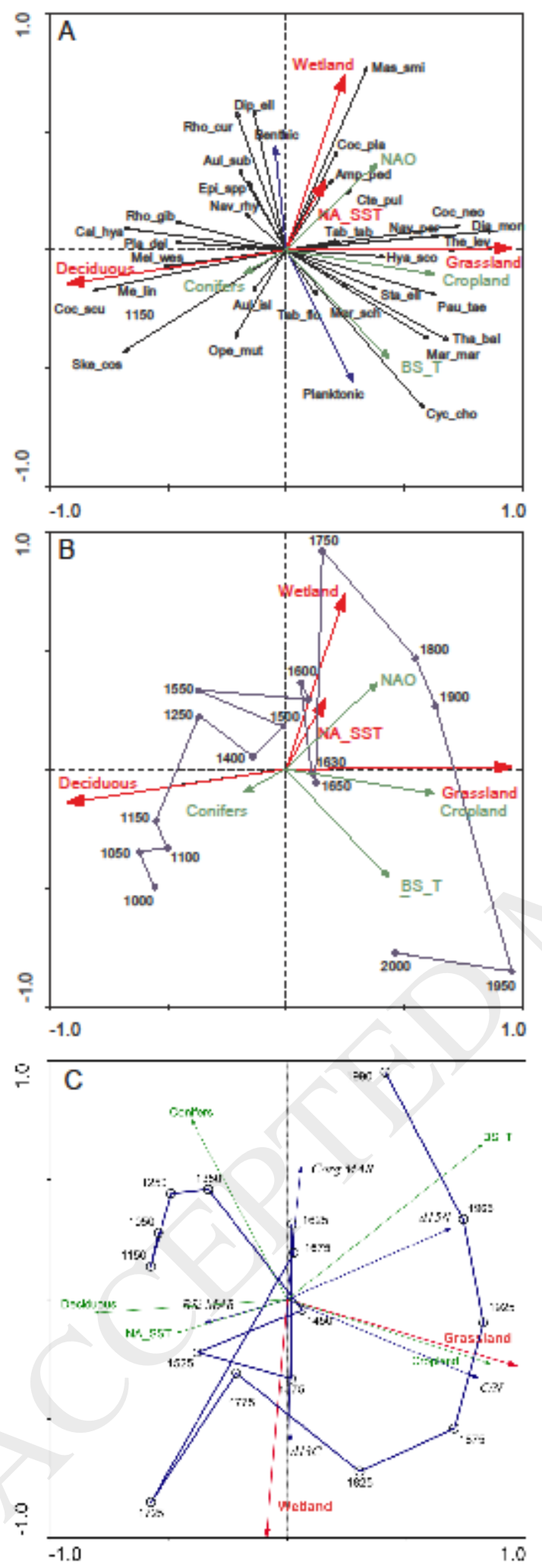


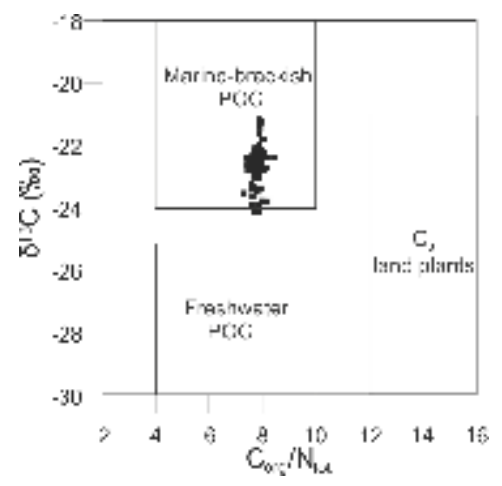




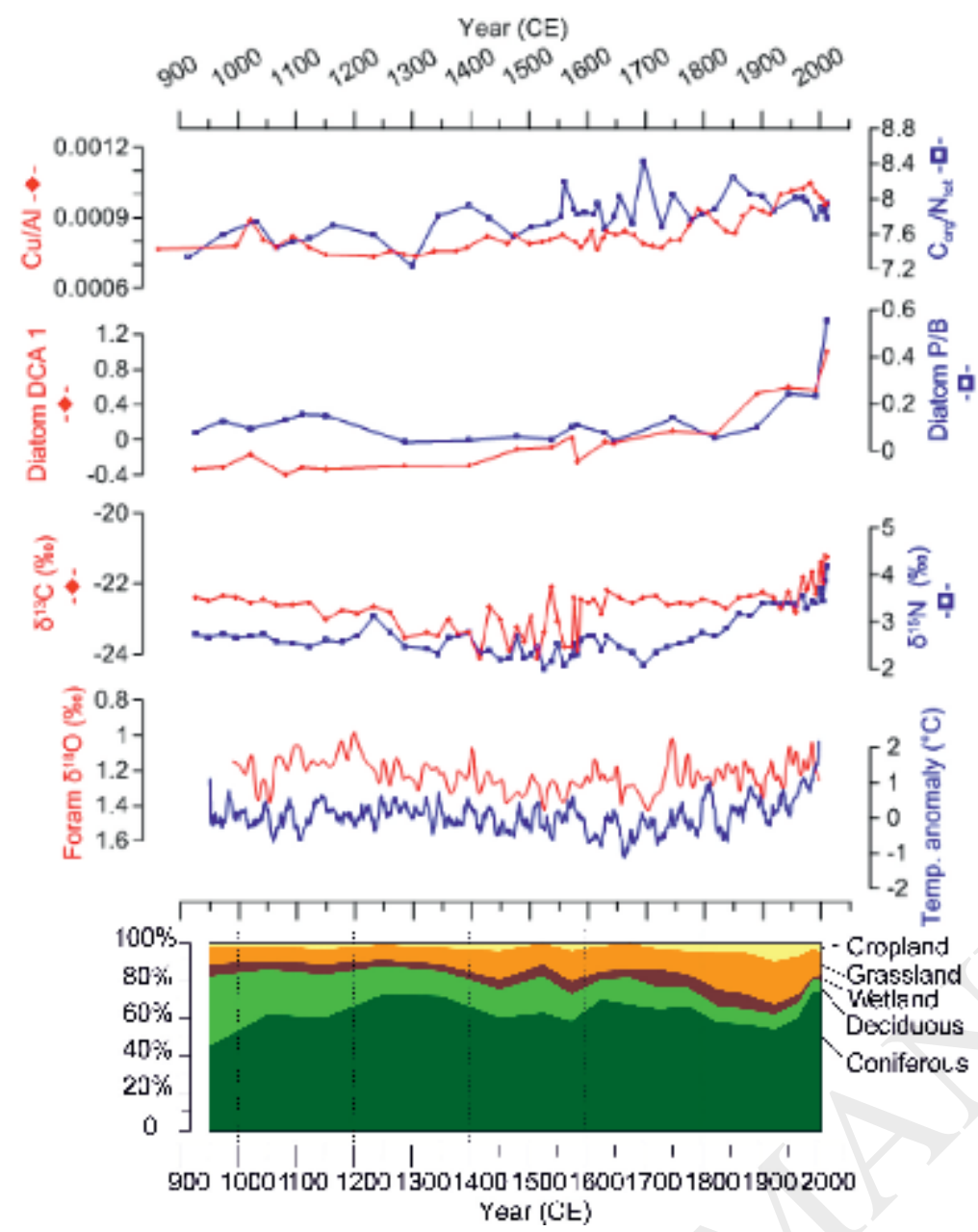

